Strategies to Achieve

Net-Zero Energy Homes:

A Framework for Future Guidelines

\title{
Workshop Summary Report
}

April 2013

Nancy McNabb

http://dx.doi.org/10.6028/NIST.SP.1140

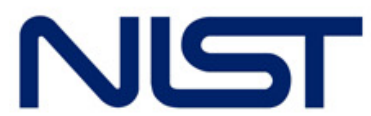

National Institute of Standards and Technology 
NIST Special Publication 1140

\title{
Strategies to Achieve Net-Zero Energy Homes: A Framework for Future Guidelines Workshop Summary Report
}

\author{
Nancy A. McNabb \\ Engineering Laboratory \\ National Institute of Standards and Technology
}

http://dx.doi.org/10.6028/NIST.SP.1140

April 2013

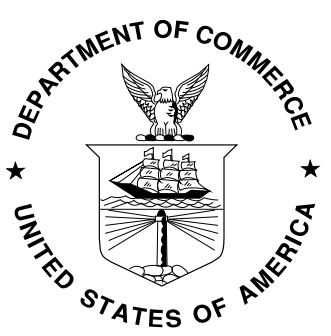

U.S. Department of Commerce Rebecca Blank, Acting Secretary

National Institute of Standards and Technology Patrick D. Gallagher, Under Secretary of Commerce for Standards and Technology and Director 
Certain commercial entities, equipment, or materials may be identified in this document in order to describe an experimental procedure or concept adequately. Such identification is not intended to imply recommendation or endorsement by the National Institute of Standards and Technology, nor is it intended to imply that the entities, materials, or equipment are necessarily the best available for the purpose.

National Institute of Standards and Technology Special Publication 1140

Natl. Inst. Stand. Technol. Spec. Publ. 1140, 48 pages (April 2013)

http://dx.doi.org/10.6028/NIST.SP.1140

CODEN: NSPUE2 



\title{
ACKNOWLEDGMENTS
}

Many thanks to all who participated in the workshop on Strategies to Achieve Net-Zero Energy Homes. The presentations and discussions that took place at the workshop provided the foundation for this report.

Special thanks are extended to plenary speakers, listed below, and to the many expert participants, shown on the next page.

\author{
Plenary Speakers \\ Peter DeMarco, International Association of Plumbing and Mechanical Officials \\ Karen Ehrhardt-Martinez, University of Colorado \\ Asa Foss, U.S. Green Building Council \\ David Karmol, International Code Council \\ Thomas Kenney, National Association of Home Builders Research Center \\ Tom Liebel, American Institute of Architects \\ Merle McBride, American Society of Heating, Refrigerating and Air-Conditioning Engineers \\ Anthony Quinn, American Society for Testing and Materials \\ Sam Rashkin, U.S. Department of Energy \\ Harvey Sachs, American Council for an Energy-Efficiency Economy
}

Nancy McNabb and members of the Energy and Environment Division within the Engineering Laboratory of the National Institute of Standards and Technology (NIST) made significant contributions to the planning and execution of the workshop and editing of this report; other technical staff from the NIST Engineering Laboratory also contributed.

Thanks are also due to the Energetics Incorporated team that provided support for workshop planning, facilitation, and preparation of the final report. This includes Joan Pellegrino, Melissa Eichner, Jordan Blackman, and Janis Tabor.

Hard copies of this report can be obtained by contacting Nancy McNabb at nancy.mcnabb@nist.gov.

Certain commercial entities, equipment, or materials may be identified in this document in order to describe an experimental procedure or concept adequately. Such identification is not intended to imply recommendation or endorsement by the National Institute of Standards and Technology, nor is it intended to imply that the entities, materials, or equipment are necessarily the best available for the purpose. 


\section{PARTICIPANTS}

Balley, Jennifer - American Society of Civil Engineers

Borowiec, Joseph - New York State Energy Research and Development Authority

Bradley, Don - Solar Strategies

Brundage, Jennifer - Analytical Sciences

Davis, Mark - National Institute of Standards and Technology

Davis, Wes - Air Conditioning Contractors of America

DeMarco, Pete - International Association of Plumbing and Mechanical Officials

Eberhardt, Karen - University of Colorado

Fanney, Hunter - National Institute of Standards and Technology

Foss, Asa - U.S. Green Building Council

Grosshandler, William - National Institute of Standards and Technology

Healy, William - National Institute of Standards and Technology

Hill, Rosaline - U.S. Department of Commerce

Hill, Terry - TJ Hill \& Associates, PHIUS Consultant

Hourahan, Glenn - Air Conditioning Contractors of America

Inks, Jeff - Window and Door Manufacturers Association

Janjua, Salim - CSSI, Inc.

Karmol, David - International Code Council

Kenney, Tom - National Association of Home Builders Research Center

Larimer, Derek - Moseley Architects

Liebel, Tom - American Institute of Architects

Liebel, Tom Marks - Thomas Architects

McBride, Merle - Owens Corning

McNabb, Nancy - National Institute of Standards and Technology

- iv -
Meyer, Richard - American Gas Association

Nell, Elizabeth - American Gas Association

Ng, Lisa - National Institute of Standards and Technology

Omar, Farhad - National Institute of Standards and Technology

Pedrick, Greg - New York State Energy Research and Development Authority

Pevsily, Andrew - National Institute of Standards and Technology

Rashkin, Sam - U.S. Department of Energy

Read, Douglas - American Society of Heating, Refrigerating and Air-Conditioning Engineers

Rioux, Nathalie - National Institute of Standards and Technology

Sachs, Harvey - American Council for an EnergyEfficient Economy

Schmidt, Amy - DOW Building and Construction

Scinta, Robert - U.S. Department of Commerce

Skulley, Sean - Washington Gas

Skye, Harrison - National Institute of Standards and Technology

Surrena, Don - National Association of Home Builders

Thompson, Morris - U.S. Department of Commerce

Turner, Jim - Association of Public and Land-Grant Universities

Ullah, Tania - National Institute of Standards and Technology

Updike, Bill - DC Department of the Environment

Vaughn, Ellen - Environmental and Energy Study Institute

Walker, Genevieve - U.S. Department of Commerce

Wills, Mark - American Society of Heating, Refrigerating and Air-Conditioning Engineers 
Photo Credits (below):

Microsoft Online

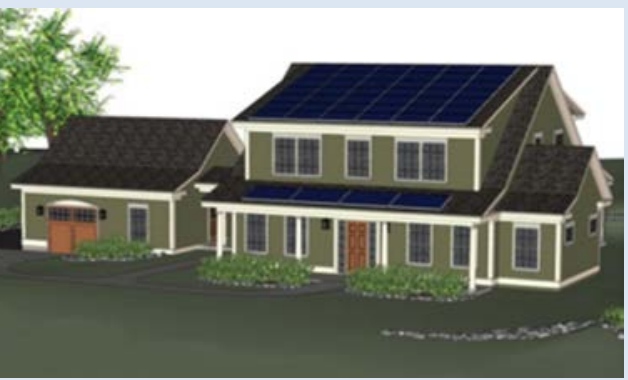

The Net-Zero Energy Residential Test Facility under construction at NIST will provide a platform to investigate effective monitoring techniques through the collection of comprehensive, highly accurate performance measurements of the energy flows within the house.

Photo courtesy of NIST. For more information:

http://www.nist.gov/el/building_environment /upload/netzerofinal.pdf

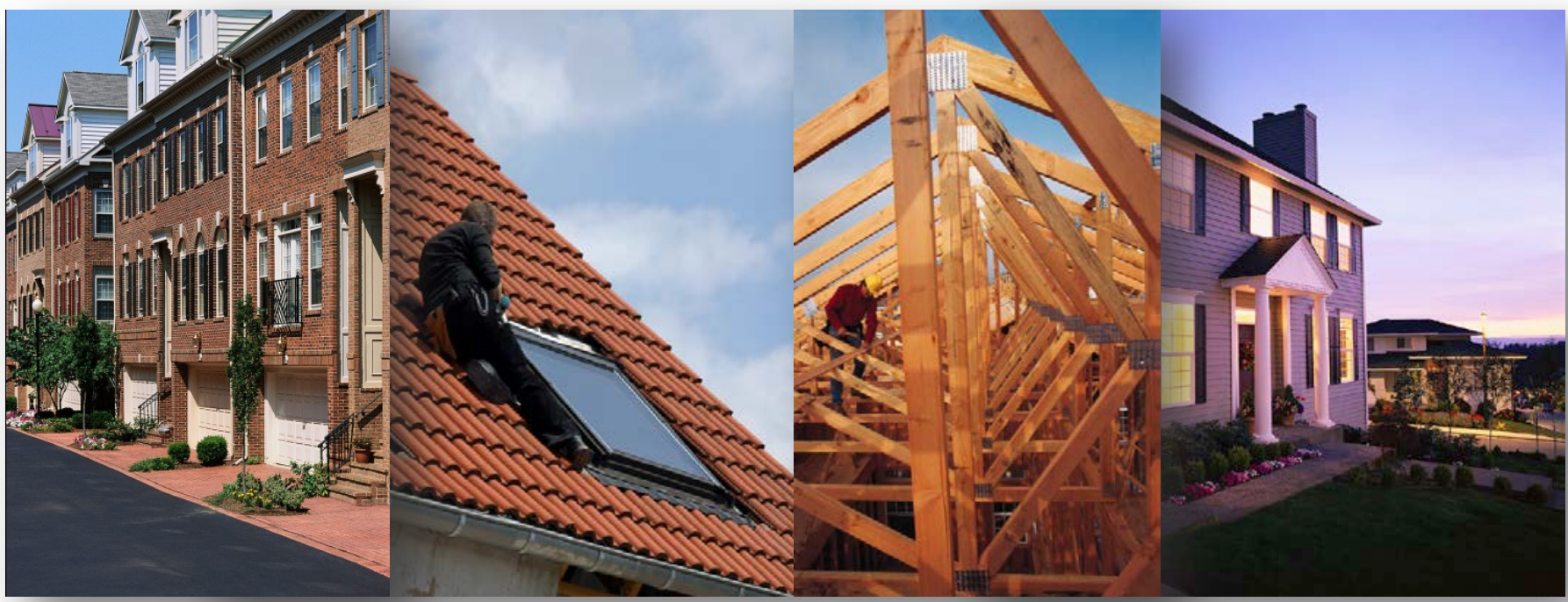





\section{TABLE OF CONTENTS}

1. Introduction ................................................................................ 1

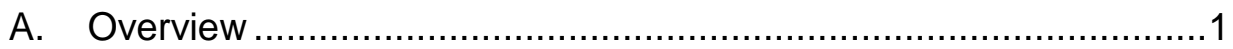

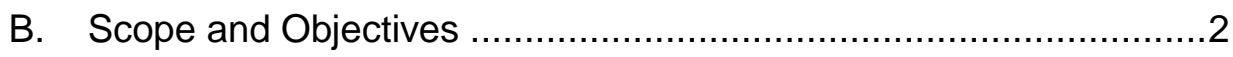

2. Design Challenges and Tools...................................................... 4

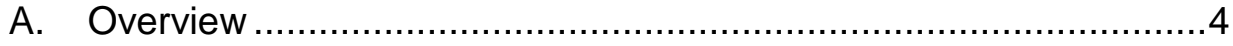
B. Key Design Aspects of Net-Zero Homes .................................... 4

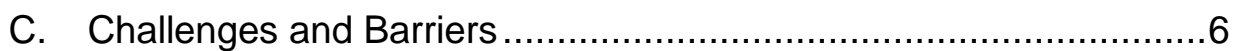

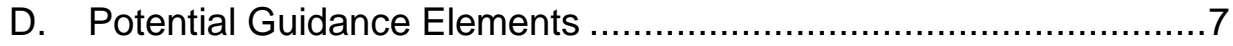

3. Technology and Equipment........................................................... 13

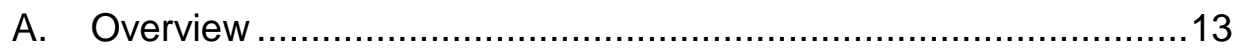

B. Key Technology and Equipment Aspects of Future Net-Zero Energy Homes ...................................................................

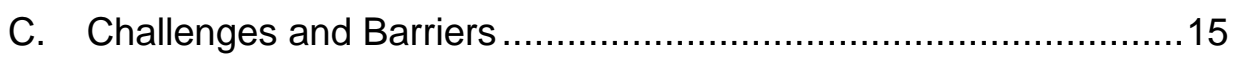

D. Potential Guidance Elements .....................................................16

4. Homeowner and Building Industry Needs and Behavior ................... 25

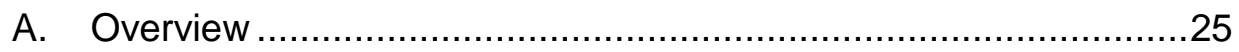

B. The Human Element of Net-Zero Energy Homes ........................26

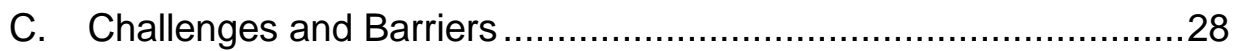

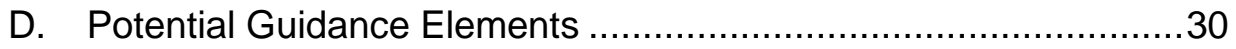

5. Cross-Cutting Considerations....................................................... 38

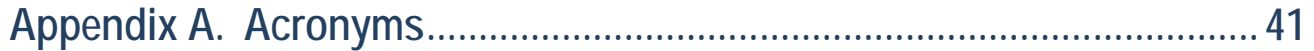


(this page intentionally left blank)

- vii - 


\section{INTRODUCTION}

\section{A. Overview}

While many of the basic concepts underpinning net-zero energy (NZE) buildings were pioneered in the United States, interest waned when energy prices declined in the early 1980s. Now, the Energy Independence and Security Act of 2007 is driving design parameters for higher levels of performance for federal buildings by 2030, and the U.S. Department of Energy (DOE) set a national goal in 2010 to achieve NZE in $50 \%$ of all commercial buildings by 2050 .

DOE projects that the total U.S. primary energy consumption for 2035 will be about 120 exajoules (or 114 quadrillion British thermal units); residential buildings will account for 21\%, as shown in Figure 1-1. ${ }^{1}$ The Residential Buildings Energy Efficiency Meeting sponsored by DOE's Building America Building Technologies Program in July 2010 identified the successes, challenges, gaps, and barriers in the area of residential energy efficiency. ${ }^{2}$ However, there is still not a clear plan for realizing NZE homes while maintaining healthy and comfortable indoor environments. A NZE residence can produce as much energy from renewable energy resources as it consumes on an annual basis. Single-family homes (including manufactured homes) consume Consumption, 2035, 114 Quadrillion Btu $85 \%$ of the energy used by the residential sector. While incorporating energy-efficiency attributes in new and existing residential buildings will help, achieving net-zero homes will require a change in design and operation of building and equipment maintenance.

\footnotetext{
${ }^{1}$ Energy Information Administration, Annual Energy Outlook with Projections to 2035, DOE/EIA0383 (Washington, DC: U.S. Department of Energy, April 2010).

${ }^{2}$ Residential Buildings Energy Efficiency Meeting, Denver, Colorado, July 20-22, 2010. http://www1.eere.energy.gov/buildings/building_america/buildings_ee_mtg.html.
} 


\section{Figure 1-2. Focus Topics}

- Design Challenges and Tools: Guidelines to integrated overall building performance and tools to facilitate the NZE home design and construction process, from pre-design through maintenance and operation.

- Technology and Equipment: Ways to guide selection and installation of the entire range of energy-efficient technologies and practices and alternative energy systems needed to achieve NZE homes (both new and existing construction).

- Owner Needs and Behavior: Ways to incorporate socioeconomic and behavioral aspects of homeowners and the residential building industry into guidelines for NZE homes.

\section{B. Scope and Objectives}

The National Institute of Standards and Technology (NIST) Measurement Science Roadmap for Net-Zero Energy Buildings Workshop Report (NIST TN 1660 - March 2010) identified a number of broad challenges to achieving NZE high-performance green building technologies. To further develop that report and to create a framework for a future guidance document on design and construction of NZE homes, NIST hosted the Workshop on Strategies to Get to Net-Zero Energy Homes on September 14, 2011. The workshop was attended by a broad segment of the residential building stakeholder community including those with interests in architecture and design, technology and equipment, real estate, and human behavior as it pertains to energy efficiency. A number of important topics were considered for achieving NZE in new and existing homes, including the potential scope of future guidelines for design, technology, and installation; elements needed to assist consumers in evaluating NZE options during home construction and purchase decisions; and factors of human behavior that will influence successful use of guidelines. 
During the workshop, attendees participated in concurrent breakout sessions centered on the focus topics shown in Figure 1-2. Within each topic, facilitators elicited perspectives from participants on several key questions, as follows:

- What are the key characteristics of future NZE homes and the residential building community?

- What are the challenges and barriers that impede the design, construction, and purchasing of NZE homes?

- What are the potential concepts that could be included in a future guidance document for the residential building community to aid in the design and construction of NZE homes?

The chapters which follow represent a compilation of responses to the questions noted above. In some of the discussions, participants were asked to cast their vote to identify some of the most important concepts. The criteria for voting was selection of the concepts that could potentially have the most impact on encouraging design and construction of NZE homes, and be implemented in the near term. The voting exercise resulted in a ranking of ideas into categories of high, medium, and lower priority. Some of the most important elements identified for inclusion in a future guidance document were subjected to more in-depth discussions in small interactive groups. These are highlighted throughout the report in the guidance element graphics found in each chapter.

The visionary framework presented here is the result of discussions among the many stakeholder groups that were represented. It is intended to aid in developing a set of future guidelines for the residential building community and homeowners as they design, construct, and operate NZE homes. While we recognize that sustainability involves more than energy, we have chosen to limit this report to NZE homes. 


\section{DESIGN CHALLENGES}

\section{AND TOOLS}

\section{A. Overview}

This topic covers strategies for whole building design and construction practices needed to achieve NZE status when building new homes and retrofitting existing homes. Rather than focus on subsystems and components, the emphasis is on a more integrated view of overall building performance. While considering all phases from pre-design to maintenance and operation, it outlines the challenges and tools that can contribute to an NZE home design and construction process. This includes the planning required for home financing, siting, layout, and seamless integration of components into a single system that reduces energy consumption while maintaining or improving indoor environmental conditions. Specific activities were identified for homeowners, designers, builders, building officials, realtors, and others to undertake in delivering, operating, and maintaining an NZE home project to achieve the promised energy-efficient performance.

\section{B. Key Design Aspects of Net-Zero Homes}

The potential characteristics of building design for NZE homes are summarized in Table 2-1. Choosing a home that has a modest footprint and integrated systems is a key to optimizing performance. Scalable and reproducible processes and quality construction can ensure design specifications are achieved without sole reliance on inspection. Selecting easy to use and maintain materials and systems results in longterm success. Educating homeowners on how to make informed energy decisions during the planning process along with implementing easily understood real-time feedback during occupancy are other critical features. 
Table 2-1. Key Aspects for Future Design of NZE Homes

\section{Whole Building Design Approach}

\begin{tabular}{|c|c|}
\hline $\begin{array}{l}\text { High } \\
\text { Priority }\end{array}$ & $\begin{array}{l}\text { - Homes are right-sized using best practices so they have a modest footprint with a } \\
\text { minimal energy/carbon footprint. } \\
\text { - All systems are integrated and sized properly, including heating, cooling, ventilation, } \\
\text { and dehumidification, to optimize the building performance. } \\
\text { - Benefits of climate responsiveness are captured by reclaiming traditional, indigenous } \\
\text { passive design techniques such as south-side windows that promote day lighting. } \\
\text { - Quality construction and comprehensive building sciences incorporate flashing, } \\
\text { sealing, framing, and other techniques to achieve a tight, well-insulated envelope. }\end{array}$ \\
\hline $\begin{array}{l}\text { Medium } \\
\text { Priority }\end{array}$ & - Quality is integral to the design so it is independent of inspection. \\
\hline $\begin{array}{l}\text { Lower } \\
\text { Priority }\end{array}$ & $\begin{array}{l}\text { - Design tools are available to assist with a whole-building approach and system } \\
\text { integration. } \\
\text { - Processes for design and construction are scalable and consistently reproducible } \\
\text { without uniformity; NZE homes can be achieved without an overly prescriptive } \\
\text { approach (freedom with boundaries, flexible designs). } \\
\text { - Design and construction processes are implemented collaboratively. } \\
\text { - Energy load is served by a variety of methods. } \\
\text { - Renewable energy is available, particularly on-site, and enables self-sufficiency. } \\
\text { - All performance goals are considered in pre-design planning. } \\
\text { - Innovation improves the design options for NZE homes over time. }\end{array}$ \\
\hline \multicolumn{2}{|c|}{ Owner Operation } \\
\hline $\begin{array}{l}\text { High } \\
\text { Priority }\end{array}$ & $\begin{array}{l}\text { - Simple systems are offered that are easy to use and maintain properly. } \\
\text { - Real-time energy metering provides valuable feedback to owners. }\end{array}$ \\
\hline $\begin{array}{l}\text { Medium } \\
\text { Priority }\end{array}$ & - NZE homes are disaster-resistant. \\
\hline $\begin{array}{l}\text { Lower } \\
\text { Priority }\end{array}$ & $\begin{array}{l}\text { - Performance can be verified post-construction and throughout the home's lifetime. } \\
\text { - NZE homes are comfortable and affordable, and have low maintenance. First-time } \\
\text { buyers can build an NZE home. }\end{array}$ \\
\hline \multicolumn{2}{|c|}{ Standards and Codes } \\
\hline $\begin{array}{l}\text { Medium } \\
\text { Priority }\end{array}$ & - Objective, measureable standards are used to draft codes. \\
\hline \multicolumn{2}{|c|}{ Water and Indoor Environment } \\
\hline $\begin{array}{l}\text { Lower } \\
\text { Priority }\end{array}$ & $\begin{array}{l}\text { - Indoor air quality and indoor environmental quality are improved, and ventilation is } \\
\text { both natural and mechanical. } \\
\text { - Water, including rainwater and grey water, is used efficiently and conserved thus } \\
\text { contributing to a low-energy/carbon home. }\end{array}$ \\
\hline \multicolumn{2}{|l|}{ Training } \\
\hline $\begin{array}{l}\text { High } \\
\text { Priority }\end{array}$ & $\begin{array}{l}\text { - Architects and builders are trained in NZE; this includes pre-construction building } \\
\text { science and integration of performance measurement and verification. }\end{array}$ \\
\hline
\end{tabular}




\section{Challenges and Barriers}

Broad challenges to improved NZE design for residential buildings include lack of consistent evaluation and valuation processes among the building community, the inability to attract investment to achieve economies of scale, and the lack of accessible proven information on how to achieve NZE. Table 2-2 provides a complete list of the challenges identified.

Table 2-2. Design Challenges and Tools - Barriers and Challenges Evaluating and Comparing Energy Performance

\begin{tabular}{|c|c|}
\hline $\begin{array}{l}\text { High } \\
\text { Priority }\end{array}$ & $\begin{array}{l}\text { - Lack of consolidated home scores that enable easy evaluation by customers. } \\
\text { - Multiple metrics so customers can weigh scores based on preferences. } \\
\text { - Too many standards, codes, and guidelines to consider. } \\
\text { - Consumers select by labels even though the result is less than optimal. }\end{array}$ \\
\hline $\begin{array}{l}\text { Lower } \\
\text { Priority }\end{array}$ & $\begin{array}{l}\text { - Lack of a standard life cycle cost approach and calculations for materials, energy, } \\
\text { water, etc. }\end{array}$ \\
\hline \multicolumn{2}{|c|}{ Valuation of Homes } \\
\hline $\begin{array}{l}\text { High } \\
\text { Priority }\end{array}$ & $\begin{array}{l}\text { - Lack of a valuation process for the entire real estate transaction process that } \\
\text { includes energy, i.e., valuation of principal, interest, taxes, insurance and energy } \\
\text { cost (PITIE) vs. valuation of principal, interest, taxes, and insurance (PITI). } \\
\text { - Continued focus of valuators on initial cost versus life cycle cost. }\end{array}$ \\
\hline \multicolumn{2}{|c|}{ Technology Selection and Building Options } \\
\hline $\begin{array}{l}\text { Medium } \\
\text { Priority }\end{array}$ & $\begin{array}{l}\text { - Inappropriate oversized heating, ventilation, and air conditioning selections for low- } \\
\text { - Lad homes. } \\
\text { - Limited propensity to offer affordable (lower energy) solutions that work (e.g., air } \\
\text { - Lack of sales infrastructure. } \\
\text { - Lack of renewable resources in some locations. } \\
\text { - Industry structure and lack of capitalization hinder development of NZE homes. }\end{array}$ \\
\hline $\begin{array}{l}\text { Lower } \\
\text { Priority }\end{array}$ & $\begin{array}{l}\text { - Market inertia favors older, less-efficient technology and practices. } \\
\text { - Maintaining NZE as do-it-yourself homeowners renovate. } \\
\text { - Lack of open-source interoperable software. }\end{array}$ \\
\hline
\end{tabular}

Standard methodologies are not available for evaluating and comparing energy performance in homes. Consumers cannot easily compare the performance of a new or existing home to see how it differs with changing patterns of behavior and energy use. The traditional home inspection process is not robust enough to verify proper installation or construction with regards to improved energy performance.

Valuation of homes does not typically include energy performance even though energy costs are often greater than taxes and insurance. Homes are designed, built, and sold for initial cost, not life cycle costs. There is no widely accepted process 
implemented throughout the entire real estate transaction to enable consumers to gain the full benefit of purchasing a home with lower maintenance costs. Most homeowners are not aware of the energy and carbon footprint of their planned or existing home and how to lower it.

Effective selection of technology, building materials, methods of construction, and siting options to achieve NZE homes is relatively difficult. Mechanical systems in buildings are often sized incorrectly, partially due to a lack of technology for lowload homes. Information on how to achieve NZE and the relevant technologies and materials of construction is dispersed. There is no sales infrastructure offering consistent and reliable solutions. The insufficient number of showcase homes in existence cannot demonstrate feasibility and cost-effectiveness or create market factors to lower costs.

\section{Potential Guidance Elements}

Some of the most important elements identified for inclusion in a future guidance document are summarized below, and described in more detail in Figures 2-1 to 2-4.

Consumer labels for new construction and existing homes: A consistent and widely used home scoring system is needed for evaluating planned/preconstruction home performance, comparing planned/preconstruction home performance to actual performance upon completion, and comparing homes for sale. Such a labeling/scoring system should include consideration of life cycle costs. Consumers could evaluate energy performance and other factors based on their own preferences using criteria that are consistently applied across homes. Home scores have the potential to encourage builders to sell and construct homes that include investments in energy efficiency, durability, and reduced maintenance costs.

Clearinghouse for available design guidelines: Information is available to assist with NZE design, but it is dispersed and from varied sources. Existing design information should be gathered, evaluated, and organized to make it more accessible and useful. After establishing a clearinghouse of existing materials, it must be maintained and reviewed periodically for gaps.

User-friendly design tools: A design tool that is widely accepted and used throughout the building community is needed to promote transparent communication. The ideal tool would have the capability to evaluate alternate design options, materials, and methods of construction to maximize building performance; link to relevant construction and safety standards; and be able to satisfy competing objectives and customer design expectations.

Valuation standards for energy costs in home financing: The cost of energy needed to power and provide heating and cooling comfort as well as acceptable 
indoor air quality (IAQ) contributes to the affordability of a home. These costs must be factored into financing a home purchase along with the principal, interest, taxes, and insurance. Properly valuing energy will create an incentive to improve energy performance and increase the value of more efficient homes. 


\section{Figure 2-1. Design Challenges and Tools Guidance Element: Consumer Labels for New Construction and Existing Homes}

\section{Description:}

A scoring system is needed for homes to enable consumers to compare energy, durability, indoor air quality, accessibility, and other factors relative to their needs during the purchase of newly constructed and existing homes. This will safeguard customer expectations and encourage the construction of NZE homes.

Building Delivery Stage: Pre-design and design review (with architect and code official), inspection during construction to ensure construction compliance, and post-construction performance testing or commissioning.

Technologies and Home Applications: All aspects of construction, design, etc., coordination and sequencing of inspections; involve mortgage lenders in the construction payment schedule.

\section{Challenges and Barriers}

- Inability to compare homes based on performance and personal preferences using consistent criteria.

- Builders that measure value according to initial cost rather than operational costs.

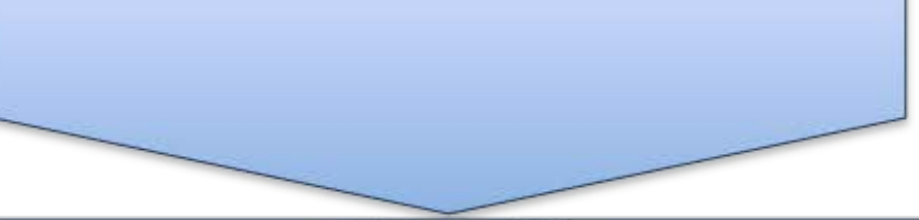

\section{Goals and Objectives}

- Compare actual performance to design plans.

- Improve design process by having a feedback loop.

- Educate consumers and encourage use of home scores during purchase.

- Create incentives to build NZE homes by factoring in a consistent valuation of operational costs.

\section{Steps to Develop/Implement Guidance Element}

- Develop clear objective metrics and standards for each element to be inspected, including procedures, tolerances, and documentation

- Develop and agree on a life cycle cost methodology.

- Get banks and insurance companies involved.

- Train designers, builders, and subcontractors.

- Certify auditors, raters, and code officials.

- Educate and coordinate with mortgage lenders.

- Develop tools on how to improve score during planning and retrofit.

\section{Measures of Success}

- Rapid education of consumers and reduced call backs.

- Scored homes have a selling advantage compared to un-scored homes.

\section{Stakeholders and Roles}

Rater/auditors: Provide audit services consistently and equitably Homebuilders/remodelers: Meet and follow the standards; educate consumers and implement scored processes

Designers: Educate and design to specified standards

Mortgage/lenders: Coordinate with builders and remodelers; offer better rates for higher-scoring homes

Realtors: Educate consumers

Homebuyers/homeowners: Request audits

\section{Existing Resources}

Energy Star (U.S. Environmental Protection Agency)

European Union Ecolabels

Certified Green Dealer Program (U.S.)

EcoLogo, conforming to ISO 14024

Global Ecolabelling Network

Carpet Research Institute Green Label Program 


\section{Figure 2-2. Design Challenges and Tools Guidance Element: Clearinghouse for Available Design Guidelines}

\section{Description:}

A readily accessible clearinghouse of design guidelines for NZE is needed to better inform the building community. Information is available to assist with NZE design, but it is dispersed and from varied sources. Information needs to be gathered, evaluated, and organized to make it accessible, and gaps need to be identified and filled.

Building Delivery Stage: Pre-design, design.

Technologies and Home Applications: New construction and retrofits.

\section{Challenges and Barriers}

- Locating all available information.

- Assessing quality from varied sources.

- Organizing resources in a coherent and accessible manner.

- Maintaining quality in step with rapid changes in knowledge base.

\section{Goals and Objectives}

- Collect, evaluate, and benchmark what is available to contribute to NZE homes.

- Maintain and continuously improve resources.

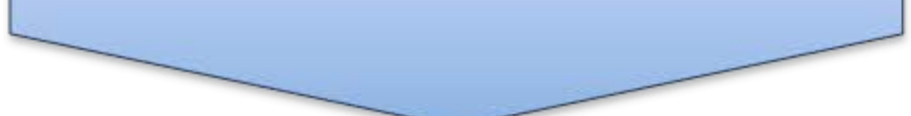

\section{Steps to Develop/Implement Guidance Element}

- Locate and compile available information for housing in a central location.

- Determine a way to organize, categorize, and evaluate information.

- Publish and maintain clearinghouse of guidelines.

- Identify gaps in available information and develop plan to address gaps with useful data.

\section{Measures of Success}

- Usefulness of tool, as measured by website visits and mobile app downloads.

\section{Stakeholders and Roles}

DOE, U.S. Department of Commerce, national laboratories:

Compile data

Industry/trade groups: Identify good information and guidelines

Private research groups: Fill gaps

Educational programs: Disseminate knowledge

Manufacturers: Use and vet guidelines

\section{Existing Resources}

DOE and other national laboratories

Passivhaus and Minergie standards

Energy Star

Private companies (Building Science Corp., Green Building

Advisor, Home Energy Magazine)

Regional programs 


\section{Figure 2-3. Design Challenges and Tools Guidance Element: User-Friendly Design Tools}

\section{Description:}

The objective is to develop user-friendly tools for use in NZE home design that will serve as a foundation for use throughout the building professions. These tools would have the capability to evaluate various design options to maximize building performance, as well as be able to link to standards and meet competing objectives and customer design expectations.

Building Delivery Stage: Pre-design, design, construction, and commissioning.

Technologies and Home Applications: Computer modeling/building information modeling, linkage to standards, easy visualization, and second software suite for homeowners.

\section{Challenges and Barriers}

- Measurement science is lacking to support critical performance -based tools. Many tools exist, but are not necessarily compatible (interoperable) with each other.

- Getting architects, builders, engineers, and planners to agree on tools.

\section{Goals and Objectives}

- Develop measurement science to enable validation of tools.

- Develop better building information modeling tools with details that are transparent to design.

- Establish education throughout professions, including schools, internships, and architecture.
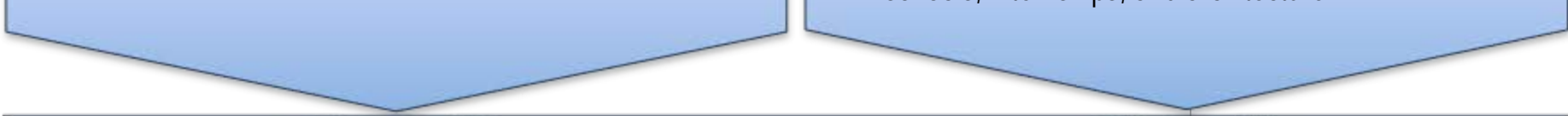

\section{Steps to Develop/Implement Guidance Element}

- Inventory existing design tools using a set of identified criteria.

- Evaluate tools to determine applicability for the user-friendly design portfolio.

- Conduct the research required to develop robust tools considering the needs of all building professions.

- Identify and pursue means of educating the building community on the availability, use, and value proposition of these tools.

\section{Measures of Success}

- Tools linked to standards are used to design NZE homes.

\section{Stakeholders and Roles}

Building Research community

SDOs

Design and construction community

Architects

Engineers

Contractors

Fabricators, equipment vendors

\section{Existing Resources}

Natural Sciences and Engineering Research Council of Canada Smart Net-Zero Energy Buildings Strategic Network

Whole Building Design Guide, National Institute of Building Sciences

Building Performance Simulation (BPS) tools: HEED, e-Quest, ENERGY-10, Vasari, Solar Shoebox, Open Studio Plug-in, Illuminating Engineering SocietySource: Shady G. Attia and André de Herde, "Early Design Simulation Tools for Net Zero Energy Buildings: A Comparison of Ten Tools" (lecture, Building Simulation 2011 Conference, Sydney, November 14, 2011). 


\section{Figure 2-4. Design Challenges and Tools Guidance Element: Valuation Standards for Energy Costs in Home Financing}

\section{Description:}

This strategy would promote the widespread adoption of a home valuation protocol that includes energy and is workable for the entire real estate transaction process. This means incorporating energy in the appraisal process, and the valuation of principal, interest, taxes, and insurance (PITI) so that it incorporates energy cost considerations to become the valuation of principal, interest, taxes, insurance, and energy cost considerations (PITIE).

Building Delivery Stage: Design, orientation, and funding for pre-design, design development, etc.

Technologies and Home Applications: Green mortgages; utility company participation in funding improvements.

\section{Challenges and Barriers}

- Complexity of addressing life cycle costs versus initial costs

- Overcoming current disregard of energy in home valuation.

- Effectively educating the financial community about energy valuation.

\section{Goals and Objectives}

- Create an effective mechanism for value analysis of home energy consumption.

- Ensure that energy valuation is a routine part of financing a home purchase, including the appraisal process.
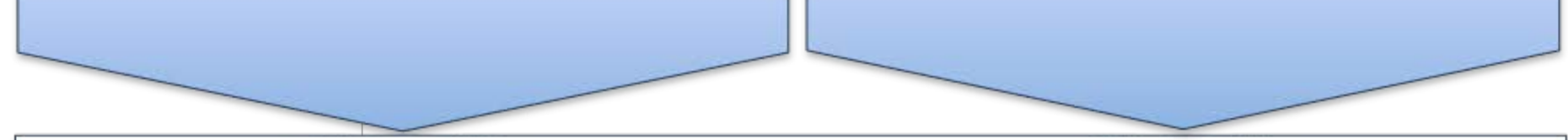

\section{Steps to Develop/Implement Guidance Element}

- Develop science-based, reliable and robust LCC models

- Work with the financing, insurance, and real estate communities to identify the best ways to incorporate energy into the valuation process for new and existing homes.

- Develop valuation models and vet with the building, insurance, and finance communities.

- Establish a standardized method for home evaluation that can be used nationally.

- Encourage widespread use of energy valuation through various mechanisms.

\section{Measures of Success}

- Cost of building (mortgage) and utilities for NZE homes is equal to or less than traditional projects.

\section{Stakeholders and Roles}

Buyers: Understand, trust, and use home valuation concepts Lenders: Vet and incorporate energy valuation in lending practices Realtors: Vet and market energy valuation as part of home purchases Appraisers: Include energy valuation in appraisals

Designers: Consider energy value in home designs

Builders: Select energy-efficient options as part of home construction and appeal

\section{Existing Resources}

Little information currently exists and new methods will need to be developed. 


\section{TECHNOLOGY AND EQUIPMENT}

\section{A. Overview}

This topic encompasses strategies for the entire range of best practices, energyefficient technologies, and alternative energy systems needed to achieve both new and existing construction of NZE homes. Building envelope technologies under consideration could include improved construction and inspection techniques to achieve more efficient walls, foundations and roofs, high-performance windows and doors; day-lighting while minimizing cooling loads; and architectural coatings that scatter and reflect ultraviolet, visible, and near-infrared radiation to reduce solar gain, or that minimize unwanted heat loss. Building system components such as heating, ventilation, and air conditioning (HVAC); lighting; and appliances all make a significant contribution to overall building energy use. Intelligent buildings, which apply a range of integrated, microprocessor-based measurement and control technologies to improve the home environment and functionality for occupants, can help to reduce energy load.

Some NZE concepts (e.g., tighter building envelopes) could potentially impact indoor air quality (IAQ). IAQ control technologies, such as heat recovery ventilation, novel ventilation concepts, and approaches to reducing outdoor air requirements, will support net-zero homes by ensuring that indoor environmental conditions are maintained and potentially improved.

Alternative energy systems can be used to produce electricity and thermal energy at the building's site, eliminating electrical transmission and distribution losses and lowering peak demand. These include solar (e.g., photovoltaics, including buildingintegrated, and both active and passive solar thermal technologies), wind (e.g., wallor roof-integrated, stand-alone), geothermal, on-site hydropower, fuel cells, and combined heat and power systems, as well as building integration of these systems. 


\section{B. Key Technology and Equipment Aspects of Future Net-Zero Energy Homes}

The aspects of technology and equipment that were identified as important for future NZE homes are summarized in Table 3-1. These considerations are not all-inclusive, but represent areas where guidelines could facilitate technology selection and use.

\section{Table 3-1. Technology and Equipment Aspects of Future NZE Homes}

\section{Building Envelope}

\begin{tabular}{|c|c|}
\hline $\begin{array}{l}\text { High } \\
\text { Priority }\end{array}$ & $\begin{array}{l}\text { - Maximizing the benefits of day-lighting and efficient light technologies will be important } \\
\text { aspects of future NZE homes to reduce lighting needs. } \\
\text { - Various materials, assemblies, and technologies (e.g., cool roofs, encapsulated } \\
\text { attics/basements, insulation exterior to framing) will minimize envelope loads (conduction, } \\
\text { solar, infiltration, and moisture). }\end{array}$ \\
\hline $\begin{array}{l}\text { Medium } \\
\text { Priority }\end{array}$ & - Triple-pane windows with ratings of R-7 and above will be employed. \\
\hline \multicolumn{2}{|c|}{ Intelligent Home Operation } \\
\hline $\begin{array}{l}\text { High } \\
\text { Priority }\end{array}$ & $\begin{array}{l}\text { - Automation and advanced controls will minimize electricity use for plug and process loads } \\
\text { (smart lights, appliances, etc.); lighting, comfort, and electronics are installed to respond } \\
\text { independently to occupants; appliances and HVAC are completely integrated; fault } \\
\text { detection diagnostics are employed; and all systems work seamlessly with the smart grid. }\end{array}$ \\
\hline $\begin{array}{l}\text { Lower } \\
\text { Priority }\end{array}$ & $\begin{array}{l}\text { - Feedback to occupants on energy management performance is possible through monitoring } \\
\text { and display systems (e.g., electricity, water). } \\
\text { - Maintaining a reasonable or allowable energy budget is part of the NZE home operation. }\end{array}$ \\
\hline \multicolumn{2}{|l|}{ HVAC } \\
\hline $\begin{array}{l}\text { High } \\
\text { Priority }\end{array}$ & $\begin{array}{l}\text { - High-efficiency, affordable systems will be readily available (HVAC/air distribution systems } \\
\text { to recover heat from air and water, hot water systems); comfort conditioning and hot water } \\
\text { generation are integrated and all distributed within the conditioned space. } \\
\text { - Right-sized equipment (e.g., smaller, more efficient) will match the lower sensible and latent } \\
\text { heat loads characteristic of NZE homes; demand will drive new and better technologies. }\end{array}$ \\
\hline $\begin{array}{l}\text { Medium } \\
\text { Priority }\end{array}$ & $\begin{array}{l}\text { - Control of airborne contaminant sources (e.g., from construction materials, furnishings, and } \\
\text { appliances) will be used to maintain IAQ in NZE homes with tighter envelopes. } \\
\text { - Improved outdoor air ventilation systems will be designed to adequately support the NZE } \\
\text { home, and not necessarily need to be integrated with the space conditioning system. }\end{array}$ \\
\hline \multicolumn{2}{|c|}{ Landscaping, Pools, and Other Site Considerations } \\
\hline $\begin{array}{l}\text { High } \\
\text { Priority }\end{array}$ & $\begin{array}{l}\text { - Site selection for NZE homes should incorporate best practices for landscaping, smart } \\
\text { irrigation, natural day-lighting, passive designs, and gray-water systems. }\end{array}$ \\
\hline $\begin{array}{l}\text { Lower } \\
\text { Priority }\end{array}$ & $\begin{array}{l}\text { - Swimming pool technologies should employ energy-saving practices, such as pool covers, } \\
\text { high-efficiency heaters and filters, and lower use of chemicals. }\end{array}$ \\
\hline \multicolumn{2}{|c|}{ On-Site Energy Generation and Storage } \\
\hline $\begin{array}{l}\text { Medium } \\
\text { Priority }\end{array}$ & $\begin{array}{l}\text { - Homes will utilize properly sized, on-site renewable/alternative energy to generate power } \\
\text { and heat, such as solar photovoltaics, solar thermal (water/whole home), fuel cells, micro- } \\
\text { turbines for cogeneration, etc.; these will potentially have energy storage capacity and } \\
\text { communicate with the smart grid to optimize pricing and meet critical electrical loads. }\end{array}$ \\
\hline
\end{tabular}




\section{Challenges and Barriers}

A number of challenges and barriers were identified that could impede the installation and efficient use of technology and equipment in NZE homes (see Table 3-2).

Table 3-2. Technology and Equipment - Barriers and Challenges

\begin{tabular}{|c|c|}
\hline \multicolumn{2}{|c|}{ Risk Factors } \\
\hline $\begin{array}{l}\text { High } \\
\text { Priority }\end{array}$ & $\begin{array}{l}\text { - Aversion to change (builders, trades, contractors). } \\
\text { - Fear of unnecessary risk, product/system failure, unintended consequences, } \\
\text { and other liabilities. } \\
\text { - Worker training expenses for new concepts. } \\
\text { - Aversion to being the first to introduce new/unproven technology. } \\
\text { - Lack of metrics and ways to measure and communicate the financial benefits of NZE } \\
\text { homes and related technology and equipment (cost-benefit, payback). }\end{array}$ \\
\hline & $\begin{array}{l}\text { - Lack of good financing mechanisms (Property Assessed Clean Energy, on-bill) and } \\
\text { an appraisal system that incorporates the value of NZE components for home } \\
\text { resale). } \\
\text { - Lack of affordable NZE building products and systems (materials, labor). } \\
\text { - Lack of large-scale technology demonstrations that prove performance and value is } \\
\text { of importance to all NZE stakeholders (manufacturers, designers, builders, and } \\
\text { homeowners). } \\
\text { - Increased complexity of NZE (unknown interactions; lack of integrated approaches } \\
\text { for design, specification, and building). }\end{array}$ \\
\hline $\begin{array}{l}\text { Lower } \\
\text { Priority }\end{array}$ & $\begin{array}{l}\text { - Unproven reliability and maintenance requirements. } \\
\text { - Cost and complexity of upgrading existing/legacy systems with new technology. } \\
\text { - Understanding total energy resource consumption (site versus source). } \\
\text { - Lack of metrics/methods for proving performance in operation, or guidelines for how } \\
\text { to cost-effectively apply fixes when performance is not achieved. }\end{array}$ \\
\hline
\end{tabular}

\begin{tabular}{l|l}
\hline \multicolumn{2}{l}{ Externalities } \\
\hline $\begin{array}{l}\text { High } \\
\text { Priority }\end{array}$ & $\begin{array}{r}\text { - Low cost of energy. } \\
\text { - Niversity and inconsistency of energy policies impacting NZE technologies. } \\
-\quad \text { Lack of consistency in rules among local, county, and municipal governments; } \\
\text { homeowner associations; condominium boards; and other entities. }\end{array}$ \\
\hline $\begin{array}{l}\text { Medium } \\
\text { Priority }\end{array}$ & $\begin{array}{l}\text { - Understanding/accommodating occupant behavior (e.g., operating and maintaining } \\
\text { the home equipment) and finding ways to automate systems so that occupant } \\
\text { intervention does not limit or lower energy efficiency. }\end{array}$ \\
\hline Standardization \\
\hline $\begin{array}{l}\text { High } \\
\text { Priority }\end{array}$ & $\begin{array}{l}\text { - Inadequate or non-uniform definitions of what constitutes NZE-good definitions } \\
\text { drive equipment solutions. }\end{array}$ \\
\hline Medium & $\begin{array}{l}\text { Lack of guidelines, standards, and codes for design/installation/operation of some } \\
\text { on-site home power generators (fuel cells, solar, micro-turbines, wind, and } \\
\text { Priority }\end{array}$ \\
\hline
\end{tabular}


Risk factors include those related to the adoption of unfamiliar technology; limited ways to measure the performance and benefits of technology; a lack of integration of NZE concepts into current financing mechanisms; and cost (both initial and operating costs). Risk aversion or a reluctance to change was identified as one of the most important barriers because it translates into reluctance on the part of builders to incorporate new technologies with unfamiliar performance histories. The lack of performance metrics is another critical barrier, as it is difficult to communicate usability, reliability, financial, and other benefits of NZE homes to consumers and the construction and finance communities.

Externalities that exert influence outside the domain of the home design and building industry can also create impediments. Diversity and inconsistency in energy policies at the federal, state, or local levels creates uncertainty about investment decisions that involve energy efficiency or on-site electricity generation. For example, in some states, the lack of an electricity interconnect law at the national level inhibits the ability of homeowners to return excess electricity generated on-site back to the local grid. Such laws are currently promulgated at the local level and are inconsistent across states (some encourage, some discourage home interconnection). The low cost of energy, or volatilities in energy costs, can also discourage building developers, designers, and owners from seeking out technologies solely for their energy-efficient attributes (i.e., the returns are uncertain).

Standardization of what constitutes an NZE home (including technology and equipment performance) is currently lacking, with many different definitions in use (e.g., high performance versus high energy efficiency). Non-uniform definitions for NZE can inhibit the marketing of design and equipment solutions for NZE homes and make it difficult for consumers to determine the quality of the NZE home. Consensus on a standard definition for NZE would provide both builders and consumers with a specified context for NZE performance, benefits, operation, and maintenance.

\section{Potential Guidance Elements}

Some of the most important elements identified for inclusion in a future guidance document are summarized below and described in more detail in Figures 3.1 through 3.6.

Guidelines for HVAC Equipment for NZE Home Applications: Drastic load reductions are possible in NZE homes. Equipment offerings will be needed to meet applications that are below 7.0 kilowatts (or 2.0 tons) for cooling and below 42 million kilojoules (or 40 million Btu) for heating. Original equipment manufacturers (OEMs) will need guidance regarding sensible/latent capacities, as well as appropriate conditions (e.g., high cubic meters per minute, but low thermal capacity units). In some cases, standards are available but contractors neglect to adhere to 
these, often using older rules of thumb resulting in oversized HVAC systems and less-efficient homes. From the contractor's perspective, the risk in not over-sizing is the increased possibility of callbacks for insufficient capacity. Extended engineering data for new, smaller systems are needed in order to factor impacts of variable climate regions. Differences with existing American Society of Heating, Refrigerating and Air-Conditioning Engineers (ASHRAE) methods of testing and Air-Conditioning, Heating, and Refrigeration Institute (AHRI) performance ratings will also need to be identified and resolved.

Automation and Control of Home Components: Guidelines are needed to establish automation and controls of home components such as lighting, appliances, plug loads, on-site generation, power, and heating. Such guidelines could facilitate the use of automation and controls as an integral strategy for reducing power usage throughout the home. Technology applications could include sensors, communications (e.g., wireless, landlines, Ethernet), energy management controls, and interaction of homes with the smart grid. Guidelines could be tailored to the interoperability opportunities between all of the relevant components. Existing standards could be adapted, such as the Smart Energy Profile 2.0, by the ZigBee Alliance, and the ASHRAE/ National Electrical Manufacturers Association (NEMA) Standard 201—Facility Smart Grid Information Model for management of electrical loads.

Guides to Aid in Maximizing Day-lighting: Simpler, better guidance is needed to encourage the effective use of day-lighting as a common component of NZE homes. Guidelines should consider climate, site, building orientation, visual transmittance of glazing/fenestration assembly, lot development, design, community context, layout (i.e., orientation of streets), and other building code requirements (e.g., egress, impact resistance, etc.). There is a need for studies that may show the secondary benefits of natural lighting, such as increased worker efficiency. Simple guidance for day-lighting design could foster greater use of this technique. Barriers include a limited understanding of lighting and heating characteristics of lights and windows, as well as a lack of models available for residential lighting applications.

Control of IAQ: The tighter construction of NZE homes requires better ventilation because elimination of contaminants by air infiltration is reduced. Guidelines are thus needed to ensure that IAQ is not compromised by NZE building construction and technology. Guidelines should address IAQ control within the unique context and environment of NZE building design. Factors to be considered include geography and weather/climate; outdoor air quality; existing and new occupant expectations; occupant activities; and occupant characteristics (e.g., age, percent of time in home, pre-existing health conditions, etc.). Control of IAQ can be achieved by limiting emissions, and better filtering, cleaning, and ventilation systems. Today, building construction materials are regulated for volatile organic compound emissions, but furniture, paints, and glues used within the home and building assemblies are often not. These can emit formaldehyde, benzene, and other harmful 
chemicals, which could be a problem for very tight homes that have reduced infiltration.

Guidelines for Building Envelope Load Control: Guidelines are needed for control of envelope loads, including solar, conduction, convection, moisture, air, and infiltration. This will require additional research or synthesis of existing research into best practices. While significant information is available in many different forms, a simpler, reliable document is needed to increase usability and facilitate greater use. Guidelines are also needed for commissioning and inspection. Factors that should be considered include full life cycle analysis (LCA), durability, building materials, construction and inspection schedules, aesthetics, historic characteristics of the surrounding community, and unfamiliarity of new technologies (e.g., new roofing and insulation materials). There is also a need to better understand the potential unintended consequences of high-performance buildings (e.g., structural deterioration, corrosion, mold, moisture in walls because of air tightness, etc.) when the systems are not integrated or appropriate construction/installation practices are not followed.

Guidance for Measuring System Performance in NZE Homes: Procedures are needed for measuring the in situ performance of original equipment and to determine rated efficiency in laboratory-controlled environments. Determining the performance of the system as-installed is currently not possible, as laboratory-type environmentally controlled testing is not available. For example, performance testing to determine how equipment performs at certain standard inside/outside temperature conditions $\left(19.4^{\circ} \mathrm{C}\right.$ or $67^{\circ} \mathrm{F}$ outside, $26.7^{\circ} \mathrm{C}$ or $80^{\circ} \mathrm{F}$ inside) does not necessarily reflect actual performance. The same equipment tested at highertemperature operating conditions could actually result in a reduced Seasonal Energy Efficiency Rating (SEER) score. The return air in tighter homes also needs to be closer to $23.9^{\circ} \mathrm{C}\left(75^{\circ} \mathrm{F}\right)$ rather than $26.7^{\circ} \mathrm{C}\left(80^{\circ} \mathrm{F}\right)$, so standard rating systems may not be adequate. Guidance is needed to ensure that there are ways to determine if the specified field energy performance is being maintained. While numerous field studies have been conducted, many lack rigor and subsequently do not extend well to multiple application conditions. OEMs will need instructions for how to properly install and conduct performance testing of HVAC components, including guidance for equipment modifications for different climate zones. For example, a SEER 16 air conditioner would be well-suited for Miami but may not be necessary in Minneapolis. 


\section{Figure 3-1.Technology and Equipment Priority Guidance Element: Guidelines for HVAC Equipment for NZE Home Applications}

\section{Description:}

With the drastic load reductions possible in NZE homes, equipment offerings are needed to meet applications that are below 7.0 kilowatts (or 2.0 tons) for cooling and below 42 million kilojoules (or 40 million Btu) for heating. OEMs will need guidance regarding sensible/latent capacities, as well as appropriate conditions. Extended engineering data will be needed to be able to factor in the impacts of variable climate regions. There is also a need to identify and resolve differences with existing ASHRAE methods of testing and AHRI performance ratings.

Building Delivery Stage: Primarily design stage.

Technologies and Home Applications: Full range of HVAC equipment to match loads at actual design conditions.

\section{Challenges and Barriers}

- Limited/nonexistent smaller-size HVAC equipment.

- Industry reluctance on redefining Methods of Tests (MOTS) and performance testing ratings.

- Non-uniform applications of building requirements by field practitioners (and NZE will add new requirements).

- Potential for code enforcement to lag significantly.

\section{Goals and Objectives}

- Identify appropriate design conditions for NZE applications.

- Identify a latent/sensible heat ratio approach for NZE applications.

- Provide OEM-specific performance ratings for design conditions and extended engineering data.

\section{Steps to Develop/Implement Guidance Element}

- Create a stakeholder group to review/assess NZE home application needs and develop guidelines for needed equipment offerings (e.g., operating conditions, humidity control, equipment sizing).

- Identify similar, existing, or overlapping guidelines and standards.

- Make recommendations for subsequent review, testing, and/or modeling.

- OEMs produce and make available equipment that is consistent with recommendations for NZE homes.

- OEMs make extended engineering and application data available to field practitioners, code officials, and others as needed.

\section{Measures of Success}

- Range of equipment becomes widely available.

\section{Stakeholders and Roles}

ASHRAE: Develop methods of testing, to scope the performance envelope AHRI/DOE: Create appropriate rating conditions

Air Conditioning Contractors of America (ACCA)/ASHRAE: Sizing, application, and installation instructions

OEMs: Identify rating conditions, make equipment available, publish performance data

Design firms/builders/contractors/code bodies: Recognize/use new equipment and data

\section{Existing Resources}

ASHRAE: Standards related to comfort, indoor air quality, and energy efficiency

ICC: Codes related to energy efficiency

DOE, NIST, AHRI, others: Energy performance ratings

ACCA: Standards on load calculations, sizing, and equipment selection American Gas Association/Consortium for Energy Efficiency/Edison Electric Institute, Gas Technology Institute, Electric Power Research Institute Energy Solution Center: Input to process as interested parties 


\section{Figure 3-2. Technology and Equipment Priority Guidance Element: Automation and Control of Home Components}

\section{Description:}

Guidelines are needed to establish automation and controls of home components such as lighting, appliances, plug loads, and on-site generation and power and heat. Guidelines can be tailored to the unique interoperability opportunities between relevant components.

Building Delivery Stage: Portions of the guidelines will be utilized during each stage of delivery.

Technologies and Home Applications: Sensors, communications (e.g., wireless, landlines, Ethernet), energy management, interoperability of various technologies in use, interaction of homes with smart grid.

\section{Challenges and Barriers}

- Lack of interoperability and limited availability of technology.

- Compatibility with and replacement of legacy systems.

- Ensuring consumers understand/use automated settings.

- Insufficient workforce with limited knowledge of home automation.

- Providing feedback to homeowners.

- Maintaining cyber security.

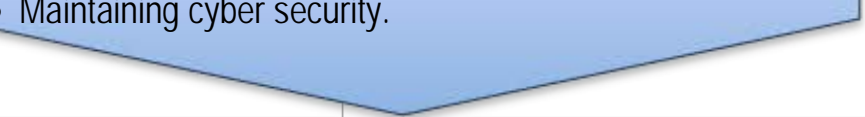

\section{Goals and Objectives}

- Provide a prioritized list for the levels of automation needed within the NZE home.

- Provide sufficient guidance to foster installation and use of automated components.

\section{Steps to Develop/Implement Guidance Element}

- Conduct a thorough review of existing guidelines and resources currently available for automation.

- Identify parameters and specifications for differentiating the levels of interoperability and automation (e.g., the hot water heater does not need to "talk" to the refrigerator, but it does need to "talk" to the dishwasher and washing machine).

- Vet guidelines with vendors and designers.

- Test guidelines with builders and provide commissioning guidelines.

- Utilize existing and emerging technologies (e.g., wireless and mobile communication devices).

\section{Measures of Success}

- Widespread adoption of home automation within NZE homes.

\section{Stakeholders and Roles}

Standards organizations: Contribute to guideline development

Equipment manufacturers: Contribute to guideline development and provide capabilities within products.

Automation and control service providers: Installation, maintenance, technical support, and information for guidelines

Government: Contribute to guideline development

Builders and system designers: Contribute to guideline development

Consumers: Adopt new technologies, use according to guidelines

\section{Existing Resources}

ASHRAE: SPC 201P - Building Information Model

Continental Automated Building Association

Institute of Electrical and Electronics Engineers: Standards for time delay

DOE/Federal Energy Management Program: Existing guidelines

Smart Energy Profile 2.0: Protocol/information modeling

Smart Grid Interoperability Panel

NIST: Existing standards 


\section{Figure 3-3. Technology and Equipment Priority Guidance Element: Guides to Aid in Maximizing Daylighting}

\section{Description:}

Guidance is needed to aid in the effective use of daylighting as a common component of NZE homes. Guidelines should consider factors of climate, site, building orientation, visual transmittance of glazing/fenestration assembly, lot development, community context, design, and layout (i.e., orientation of streets), as well as other building code requirements (e.g., egress, impact resistance).

Building Delivery Stage: Primarily pre-design and design stages.

Technologies and Home Applications: Passive solar designs, artificial lighting, and heating and cooling via daylighting.

\section{Challenges and Barriers}

- Lack of understanding of daylighting's benefits.

- Prescriptive limitations on allowable glazing area (window-towall ratio).

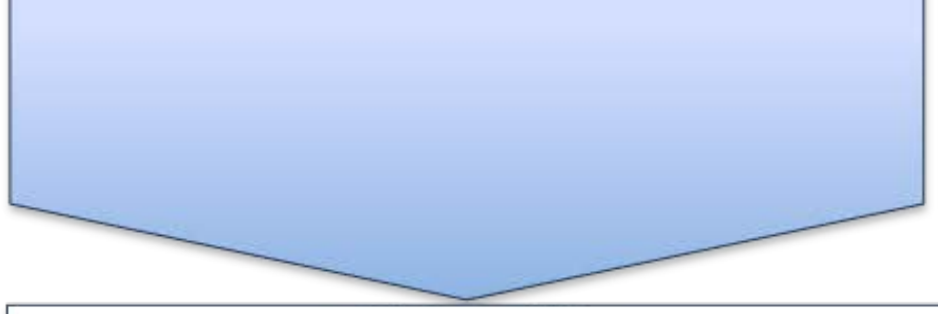

\section{Steps to Develop/Implement Guidance Element}

- Conduct a literature search of existing guidelines and resources.

- Identify all daylighting benefits beyond reduction in energy use.

- Engage the fenestration and lighting industries, designers, and builders to define needs and topics to be covered in guidelines.

- Vet guidelines with appropriate stakeholders.

- Provide illustrative examples of best practices.

\section{Measures of Success}

- Daylighting for benefits beyond energy reduction becomes accepted practice or option at pre-design and design stages.

\section{Stakeholders and Roles}

Architectures and designers: Input to guidelines

Fenestration industries: Input to guidelines

Lighting/electrical manufacturers: Input and vetting of guidelines,

installation of equipment

Passive solar design professionals: Input to guidelines and design process

Builders: Vetting and use of guidelines

\section{Goals and Objectives}

- Reduce heating, cooling, and artificial lighting loads and use.

- Enhance indoor environmental quality.

- Successful use of daylighting widely demonstrated.

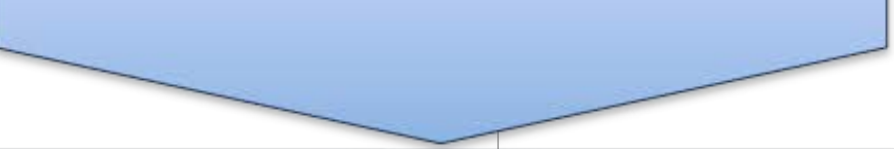




\section{Figure 3-4. Technology and Equipment Priority Guidance Element: Control of IAQ}

\section{Description:}

Guidelines are needed to ensure that IAQ is not compromised by NZE building design and technology. These guidelines should address IAQ control while considering the unique aspects of NZE buildings. Factors to be considered include geography and weather/climate; outdoor air quality; existing and new occupant expectations; occupant activities; and occupant characteristics (e.g., age, percent of time in home, pre-existing health conditions, etc.).

Building Delivery Stage: All stages.

Technologies and Home Applications: Envelope tightness, ventilation systems, materials and furnishings, filtration and air cleaning, moisture management (envelope, cooling exhaust), and occupant activities.

\section{Challenges and Barriers}

- Lack of methods for ensuring IAQ is maintained in NZE buildings.

- Balancing IAQ with energy drivers for varying occupant expectations.

- Difficulty quantifying health and comfort benefits.

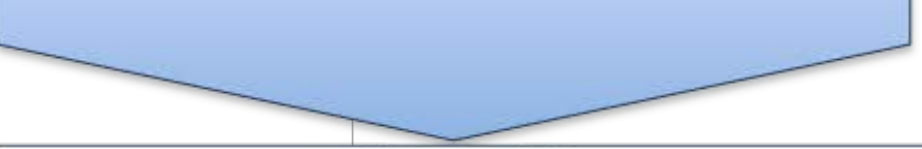

\section{Goals and Objectives}

- Maintain (if not improve) IAQ performance in an energyefficient manner.

- Provide for the health and comfort of the occupants while maintaining a balance with NZE technologies and design.

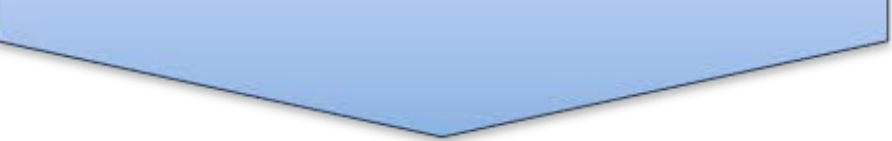

\section{Steps to Develop/Implement Guidance Element}

- Identify existing documents, standards, and studies/reports that will help to define the scope of the guidelines, specifically pertaining to NZE buildings.

- Engage stakeholders in the guideline development process.

- Define guidance scope and process for development.

- Develop, review, and approve guidelines for dissemination; determine an effective process/mechanism for publication, raising awareness, and fostering use of guidelines.

- Evaluate impacts and identify gaps for additional efforts.

\section{Measures of Success}

- Adoption of the guidelines resulting in NZE homes with sufficient or improved IAQ.

\section{Stakeholders and Roles}

ASHRAE: Contribute to guidelines

Federal agencies (EPA, HUD, Department of Construction Services, U.S. Department of Commerce, DOE, Consumer Product Safety Commission): Contribute to and vet guidelines

Industry groups (e.g., paint and adhesive manufacturers, etc.): Contribute to and vet guidelines

Trade groups (U.S. Green Building Council, National Association of Home Builders, American Institute of Architects, AHRI, NAFA, ACCA): Contribute to and vet guidelines; incorporate in design processes

Code bodies: Contribute to and vet guidelines

\section{Existing Resources}

ASHRAE 62.2 Requirements

EPA: Indoor Air Plans

Emissions Standards: Green Seal, State of California, Carpet and Rug Institute U.S. Green Building Council: Leadership in Energy and Environmental Design for Homes

National Association of Home Builders: Standards 


\section{Figure 3-5. Technology and Equipment Priority Guidance Element: Guidelines for Building Envelope Load Control}

\section{Description:}

Guidelines are needed to address envelope loads, including solar, conduction, convection, moisture, and infiltration. This will require additional research to synthesize existing research into best practices. Guidelines are also needed for commissioning and inspection. Factors that should be considered include full life cycle analysis (LCA), durability, building materials, construction and inspection schedules, aesthetics, historic characteristics of the surrounding community, and unfamiliarity of new technologies (e.g., new roofing and insulation materials).

Building Delivery Stage: All stages, but especially construction and commissioning, where gaps exist.

Technologies and Home Applications: Insulation, house wrap/moisture/air barriers, windows, siding, drainage plain, orientation, air sealing, cool/green roofs, foundation insulation/water proofing, conditioned/unconditioned interfaces.

\section{Challenges and Barriers}

- Variability in the quality of construction (i.e., if done poorly, the entire system could fail).

- Tradeoffs with daylighting and energy efficiency.

- Higher costs of technology (e.g., spray foam insulation).

- Misconceptions about tight buildings (e.g., mold issues).

\section{Goals and Objectives}

- Reduce loads while accounting for cost benefit or LCA.

- Avoid side effects, for example, air/moisture infiltration.

- Inspect at rough in to fix problems early in construction stages.

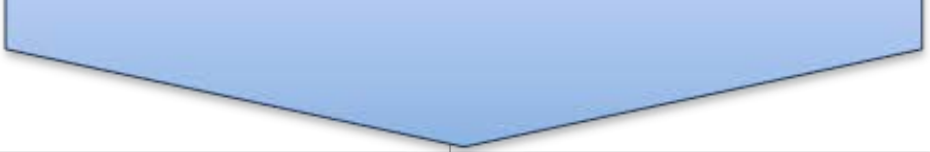

\section{Steps to Develop/Implement Guidance Element}

- Collect and assess existing building envelope guidance (e.g., DOE Better Buildings, others).

- Engage stakeholders in the guideline development process; define the scope of guidelines.

- Draft, review, and approve guidelines.

- Pursue market transformation to promote use of guidelines.

- Evaluate impacts of use, assess lessons learned, and continue to update codes and standards to maximize envelope efficiencies.

\section{Measures of Success}

- Envelope efficiencies that reduce HVAC loads to maximum cost effective capacity.

\section{Stakeholders and Roles}

ASHRAE/American Society for Testing and Materials: Contribute to guidelines

Federal agencies and laboratories (EPA, HUD, DOE, U.S. Department of Commerce, Lawrence Berkeley National Laboratory, Oak Ridge National Laboratory, National Renewable Energy Laboratory, Pacific Northwest National Laboratory): Provide information and research to support guideline development

Industry (air conditioning contractors, manufacturers of windows/doors, insulations, etc.) Contribute to and vet guidelines

Trade groups and Code Bodies (North American Insulation Manufacturers Association, U.S. Green Building Council, International Code Council, National Association of Home Builders, American Concrete Institute, American Institute of Architects, Building Performance Institute, Home Energy Rating System): Contribute to and vet guidelines

\section{Existing Resources}

ICC: International Energy Conservation Code ${ }^{\mathrm{TM}}$ (IECC)

ASHRAE: 90.2 requirements

DOE: Building America, Better Buildings

U.S. Green Building Council: Leadership in Energy and Environmental Design for Homes

National Association of Home Builders: Green Home Guide

American Society for Testing and Materials: Standards

Building Performance Institute, Home Energy Rating System, Residential Enerav Services Network 


\section{Figure 3-6. Technology and Equipment Priority Guidance Element: Guidance for Measuring System Performance in Netzero Energy Homes}

\section{Description:}

Procedures are needed for measuring the in situ performance of original equipment and to determine rate "box" efficiency in laboratory-controlled environments. It is difficult to confirm whether performance is being maintained in field applications due to the lack of performance measurements under laboratory-controlled conditions. Guidance is needed to ensure that there are ways to determine if performance is being maintained. There have been numerous field studies conducted that lack rigor, and subsequently do not extend well to other application conditions.

Building Delivery Stage: Primarily commissioning and operation.

Technologies and Home Applications: New metrics, new measurement devices accurate enough to determine energy flows relevant to NZE homes.

\section{Challenges and Barriers}

- Difficulty comparing and contrasting performance when field conditions rarely match the design/rating conditions.

- Lack of methods and tools for measuring performance of NZE homes during commissioning and operation stages.

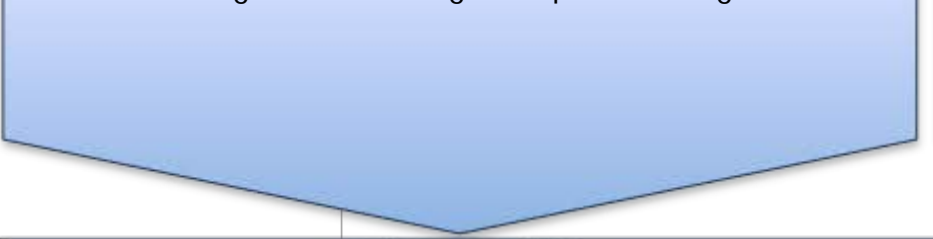

\section{Steps to Develop/Implement Guidance Element}

- Assess relevant current literature (little is available).

- Engage stakeholders to develop the scope and requirements for procedures and guidelines.

- Draft, review, and approve guidelines.

- Pursue market transformation to promote use of guidelines.

- Evaluate impacts of use and assess lessons learned.

\section{Measures of Success}

- Procedures that are accurate, repeatable, and cost-effective become available.

\section{Stakeholders and Roles}

ASHRAE, AHRI: Contribute to guidelines

OEMs: Contribute and vet guidelines

Trade/other groups (National Association of Home Builders, Building Performance Institute, Residential Energy Services Network): Contribute to and vet guidelines

Energy advocates (American Council for an Energy-Efficient Economy, Consortium for Energy Efficiency): Market transformation

\section{Goals and Objectives}

- All homeowners review "as installed" performance and understands what is expected for an NZE home.

- Ongoing maintenance adequately minimizes performance degradation.

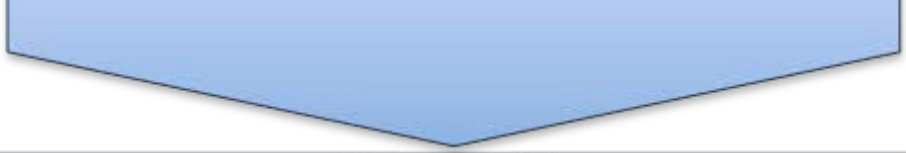




\section{HOMEOWNER AND BUILDING INDUSTRY NEEDS AND BEHAVIOR}

\section{A. Overview}

This topic encompasses strategies for addressing the needs and behavioral patterns of the residential building industry as well as homeowners as they pertain to energy efficiency. Gaining greater insight into social, cultural, psychological, and economic influences can help identify ways to motivate better energy behaviors and decision making. In theory, advanced technologies combined with best practices afford great potential for improving energy efficiency, but, in practice, realizing this potential has proven difficult. Making significant, measurable progress requires large numbers of individuals to act-and each person's actions are affected by many factors.

Strategies to encourage energy-efficient choices are further complicated by a limited understanding of some of the human dimensions of individual decision making and action-taking. The same is true for communities of individuals working together, such as in the building industry. Theory states that when given the choice to invest in a product that is more energy efficient (and has low risk), a consumer is likely to adopt the technology. In reality, the actions of individuals often do not follow this rational economic model.

A framework for the design and construction of NZE homes will require the incorporation of elements that influence and motivate smart energy decisions and behaviors. Research on energy and behavior in the home has revealed a number of trends, including the following:

- Residential energy use results from basic home infrastructure (the characteristics of buildings and equipment) multiplied by the elements of end-use (e.g., indoor temperature, the frequency and intensity of appliance operation). 
- Behaviors that affect efficiency can produce savings that are greater and last longer because they are embedded in the infrastructure.

- Efficiency improvements sometimes save less energy than possible because of "rebound" effects. These occur when people use the money saved to improve well-being in ways that may be energy intensive (e.g., increasing comfort levels, more appliances/electronics).

- Energy-efficiency savings are attractive because people do not usually associate them with a sacrifice of well-being.

Drawing from this research and lessons learned by experienced practitioners relevant to consumer behavior, a number of areas were identified for which guidelines could be developed to influence the behavior of designers, builders and homeowners targeted toward NZE homes.

\section{B. The Human Element of Net-Zero Energy Homes}

Future homes will need to take into account human behavior and needs during the design, construction, maintenance, and operation stages in order to achieve NZE. The potential characteristics of such homes are summarized in Table 4-1.

It is expected that homes will be designed so that owners can monitor performance with information that is easy to understand, includes meaningful context, and will provide a means for owners to effortlessly control energy use. Consumers will be more motivated to achieve NZE and therefore more involved in designing their NZE homes if relevant and understandable information and an accepted design process that encourages greater homeowner participation is available. Government incentives could provide support and encourage cost-effective private financing for energy efficient home construction and retrofits. Home appraisers will be educated to recognize the extra investment represented by NZE home design features and systems. Ultimately, NZE homes will be designed and built in a way that engages and empowers people to waste less energy and improve energy purchase decision making. 
Table 4-1. Vision for the Human Element of NZE Homes

Home Performance and Consumer Usability

- NZE homes are performance-based and:

- Designed so that the owner can easily operate the home energy-efficiently,

High supported by external monitoring and controls (e.g., controls that promote smart Priority energy use).

- Engage people to live sustainably (and reduce waste) through technology choices and everyday practices.

- Low-energy and low-maintenance, inside and out (from the furnishings to the yard work).

\begin{tabular}{|c|c|}
\hline \multicolumn{2}{|c|}{ Consumer Awareness and Feedback Mechanisms } \\
\hline $\begin{array}{l}\text { High } \\
\text { Priority }\end{array}$ & $\begin{array}{l}\text { - Consumers have a sense of the impact of their behavior, see the benefits of NZE } \\
\text { homes to both sustain and improve their quality of life, and accept change from the } \\
\text { norm. }\end{array}$ \\
\hline $\begin{array}{l}\text { Medium } \\
\text { Priority }\end{array}$ & $\begin{array}{l}\text { - Energy consumption, costs, and other factors are monitored real-time by owners, } \\
\text { occupants, and managers in an understandable format tailored to each type of user } \\
\text { and designed to influence their decisions. } \\
\text { - Homeowners are empowered by the information to make smart choices regarding } \\
\text { both energy consumption and technology purchases. } \\
\text { - Performance feedback to consumers induces action (e.g., alarm sounds, flashing } \\
\text { lights). }\end{array}$ \\
\hline $\begin{array}{l}\text { Lower } \\
\text { Priority }\end{array}$ & $\begin{array}{l}\text { - Real-time data from a smart grid is available in usable form for use by users, buyers, } \\
\text { etc., in making decisions. } \\
\text { - Utilities are able to: } \\
\text { - Provide better feedback to owners/consumers than is the norm today. } \\
\text { - Provide comparisons with others in the neighborhood or community as a "social } \\
\text { norm" type of feedback. } \\
\text { - Information includes appropriate context so that it is meaningful to consumers. }\end{array}$ \\
\hline \multicolumn{2}{|c|}{ Consumer-Enabled Design } \\
\hline $\begin{array}{l}\text { High } \\
\text { Priority }\end{array}$ & $\begin{array}{l}\text { - Through further studies and analyses, the building design and construction industries } \\
\text { understand what "consumer behavior" means in the context of NZE homes ("good" } \\
\text { vs. "bad"), as well as the conditions that influence consumer decisions, and design } \\
\text { and build homes accordingly. }\end{array}$ \\
\hline $\begin{array}{l}\text { Lower } \\
\text { Priority }\end{array}$ & $\begin{array}{l}\text { - Homebuyers participate in designing homes to their specification, not just the number } \\
\text { of rooms, baths, etc., but also energy efficiency and other options. }\end{array}$ \\
\hline \multicolumn{2}{|c|}{ Finance and Investment } \\
\hline $\begin{array}{l}\text { High } \\
\text { Priority }\end{array}$ & $\begin{array}{l}\text { - Government incentives provide support and encourage cost-effective private } \\
\text { financing for energy efficient home construction and retrofits. } \\
\text { - Home appraisers are educated to recognize the extra investment represented by NZE } \\
\text { home design features and systems. }\end{array}$ \\
\hline
\end{tabular}




\section{Challenges and Barriers}

The broad challenges to design, construction, maintenance, and operation of NZE homes involve behavioral factors that affect not just homeowners and rental property owners/managers, but designers, builders, and other key players in the housing market. Table 4-2 outlines the major behavioral challenges.

Table 4-2. Needs and Behavior - Barriers and Challenges

\begin{tabular}{l}
\hline Quality and Amount of Information \\
\hline \begin{tabular}{l|l} 
High \\
Priority
\end{tabular} \\
$\begin{array}{l}\text { - Lack of feedback mechanisms for consumers. } \\
\text { - Limited information for consumers to use in setting goals, planning an efficient } \\
\text { - Livergent utility interests and control over energy use data can be at cross-purposes to } \\
\text { efficiency and distributed energy. }\end{array}$
\end{tabular}

\section{Value Proposition of the NZE Home}

\begin{tabular}{|c|c|}
\hline $\begin{array}{l}\text { High } \\
\text { Priority }\end{array}$ & $\begin{array}{l}\text { - Higher levels of consumption and inefficient energy choices (e.g., larger homes) due to } \\
\text { cultural values, status, and identity. } \\
\text { - Invisibility of home energy consumption and technology purchase decisions. } \\
\text { - Limited new construction that can be retrofit later to achieve NZE. }\end{array}$ \\
\hline $\begin{array}{l}\text { Medium } \\
\text { Priority }\end{array}$ & $\begin{array}{l}\text { - Lack of visible, compelling arguments for NZE homes. } \\
\text { - Limited monetary incentives for builders for NZE or higher-efficiency technology. }\end{array}$ \\
\hline $\begin{array}{l}\text { Lower } \\
\text { Priority }\end{array}$ & $\begin{array}{l}\text { - Little monetary incentives for consumers to decrease use of energy from the grid } \\
\text { (besides a lower monthly bill). } \\
\text { - Privacy concerns about energy consumption monitoring, tracking, and reporting. } \\
\text { - Consumer perception that NZE homes are unattractive and lack modern technology }\end{array}$ \\
\hline \multicolumn{2}{|c|}{ Education and Training } \\
\hline $\begin{array}{l}\text { High } \\
\text { Priority }\end{array}$ & $\begin{array}{l}\text { - Insufficient NZE technology and equipment training and education. } \\
\text { - Lack of skilled workforce and workers aware of NZE (all building skills). } \\
\text { - Shortcomings in professional credentials and education at vocational/technical schools } \\
\text { how systems should function). } \\
\text { - Lack of competent enforcement and inspectors to ensure the home is performing up to } \\
\text { design expectations. }\end{array}$ \\
\hline \multicolumn{2}{|c|}{ Investment Costs } \\
\hline $\begin{array}{l}\text { Medium } \\
\text { Priority }\end{array}$ & $\begin{array}{l}\text { - Higher construction costs for both retrofitting and new construction are not competitive } \\
\text { with traditional homes. } \\
\text { - Uncertain return on investment; consumers are not willing to pay extra. } \\
\text { - Available NZE retrofits are not scalable and are costly to customize and install. } \\
\text { - High cost of technology to achieve the last } 10 \% \text { of an NZE home. } \\
\text { - Prohibitive cost of on-site renewable energy. }\end{array}$ \\
\hline \multicolumn{2}{|c|}{ Policies and Regulations } \\
\hline $\begin{array}{l}\text { Lower } \\
\text { Priority }\end{array}$ & $\begin{array}{l}\text { - Lack of unique incentives to make NZE attractive (e.g., tying consumer carbon credits } \\
\text { to personal benefits, such as education credits). } \\
\text { - Zoning, regulations, and buildings codes that do not encourage NZE homes. }\end{array}$ \\
\hline
\end{tabular}


The quality and amount of information homeowners receive is insufficient. Consumers require information that is useful, timely, and understandable to be able to make the energy purchase and consumption decisions necessary to achieve NZE for new and existing homes. Energy usage feedback mechanisms need to provide consumers with information that they can use to set goals, plan, and make long-term investment decisions. Data that allow for comparison with neighbors and others in the community and could provide benchmarks for change is currently lacking. Furthermore, the interests of utilities, and the data they provide, are sometimes at cross-purposes to the needs of homeowners wishing to achieve greater energy efficiency.

Convincing homebuyers and builders of the value proposition of NZE homes presents numerous challenges. Buyers' decisions are driven by values and sometimes by concerns of status that promote inefficient energy choices and higher levels of consumption. Home energy consumption and technology purchase decisions are sometimes invisible issues. Energy consumption is not performancebased (unlike the gas mileage of vehicles), and using electricity is currently not a very tangible action (such as filling up the gas tank of a vehicle). Privacy concerns about energy consumption monitoring, tracking, and reporting are also a potential barrier.

Builders are also not fully convinced of the value of NZE homes. There is little monetary incentive for builders to construct NZE homes or even to build in greaterthan-average energy efficiency because they will not reap the benefits during home operation. The lack of monetary incentive applies to the new construction of NZEready homes as well; today's new construction is not being built for ease of subsequent NZE retrofits.

Education and training in NZE technologies and equipment are lacking for both the workforce and consumers. This makes it difficult for consumers to make informed choices about what technology options are available when selecting home components. The building construction workforce is insufficiently educated about NZE technologies (both what is available and how to properly install and maintain the components for optimum efficiency). Also lacking is a competently trained building enforcement and compliance workforce that could ensure performance during the commissioning and maintenance phases. A well-trained workforce will be better able to readily incorporate NZE technologies into new and existing homes, understand the guidelines available, and help to ensure that technologies will be operating with the rated efficiency after installation.

Investment costs are too high to encourage a transformation in consumer decisions. Importantly, construction costs - both for retrofits and new construction-are not yet competitive with traditional homes. This would be less of a barrier if the return on investment was clear to consumers, but it is not, and consumers may not be 
willing to pay the extra investment costs for NZE homes. The cost of achieving the last $10 \%$ of energy performance is often prohibitive and renewables are not available in some locations. Currently, retrofits to NZE within the home boundary are not cost-effective. A significant issue is the prohibitive cost of on-site renewable energy, which is necessary to achieve NZE. Furthermore, in general, when energy prices are low, there are fewer incentives to invest in energy efficiency.

Policies and regulations are insufficient to induce the construction of NZE homes and purchase of energy-efficient technology, or in some cases are structured such that they hinder NZE homes. Zoning regulations and building codes ultimately will need to be revised to encourage the widespread design, construction, and purchase of NZE homes. Progressive policies that recognize energy use may not be effective or sustainable over the long term; rather, incentives for higher-performance homes may be necessary to make NZE attractive.

\section{Potential Guidance Elements}

Some of the most important elements identified for inclusion in a future guidance document are summarized below and described in more detail in Figures 4.1 to 4.6.

Green energy guidelines for communities and individuals: The goal is to design communities that have small-scale energy systems that create incentives for good energy behaviors throughout the community. Little thought has gone into guidelines on how to design communities with small-scale clean energy production that will create incentives for individuals to follow and adapt communal behaviors for efficient energy use. Well-crafted guidelines could abet energy independence at the community level and the individual home level, and encourage collaborative learning through community practice.

Guidelines for collection and analysis of home energy data: This effort would support technology to collect, analyze, and provide energy data to users in an accessible format. A major barrier to achieving NZE homes is the lack of access by homeowners to relevant, understandable, real-time information on energy consumption. Two sets of guidelines could be drafted to improve homeowner access to this data: for design professionals on the development of appropriate and useful technology, and for builders and consumers on the implementation, operation and maintenance of the technology.

Guide to building and marketing high efficiency homes: Builders and developers could benefit from guidelines on how to profitably build and market high-efficiency houses for diverse market segments. The guidelines would drive broader builder participation in high-efficiency home markets, and foster demonstration of building techniques and practices that increase energy efficiency without significantly raising construction costs. 
Mass purchase to attract investment in producing NZE homes: A high-volume purchase could spur innovation in industrial design and manufacturing processes to dramatically reduce the cost of NZE homes and demonstrate their value. Attracting investment in industrial production and acceptance of mass fabrication among builders and trades could also dramatically reduce the costs of public and government housing.

Buyer/owner/operator guide: A guide is needed that clearly explains how the home functions as a whole system, and how to operate and maintain individual systems within it. Such a guide would increase the knowledge of homebuyers and homeowners so that they can make better purchase and consumption decisions as well as raise their comfort level with the concept of NZE homes.

Education and credentialing: Expansion of technical school and professional school curricula is needed to support design, construction, and maintenance of NZE homes. Credentialing will help consumers recognize qualified experts and build expertise over time as the base of NZE knowledge grows. 


\section{Figure 4-1. Owner Needs and Behavior Priority Guidance Element: Green Energy Guidelines for Communities and Individuals}

\section{Description:}

Communities that are based on clean, efficient energy systems promote good "energy behavior." Small-scale green energy production guidelines are needed to create incentives for individuals to follow and adapt the same behavior. Well-crafted guidelines could encourage energy independence at the community and individual home levels, as well as encourage collaborative learning through community practice.

Building Delivery Stage: All delivery stages.

Technologies and Home Applications: Renewable energy production, management, and control (community scale); expanded data sources (diverse data); and feedback mechanisms for metrics.

\section{Challenges and Barriers}

- Third-party involvement/lack of information targeted to homeowners.

- Utility and other regulations that hinder or limit community and individual energy-efficiency practices and choices.

- Difficulty building consensus for good energy choices.

\section{Goals and Objectives}

- Energy independence at the community level and at the individual level.

- Collaborative learning through community practice.

- Immediate expansion of participation from household to community levels.

\section{Steps to Develop/Implement Guidance Element}

- Establish processes, i.e., roadmaps/pathways to create guidelines.

- Work with designers and builders to develop scope.

- Involve relevant stakeholders (utilities, owners, local and state government).

- Establish operational planning and oversight for guidelines.

- Identify ways to measure planned versus actual performance-metrics, measures.

- Identify and engage third-party vendors/service providers.

\section{Measures of Success}

- A significant number of communities incorporate small-scale energy systems.

- A significant number of communities with such systems achieve energy independence or near-energy independence.

\section{Stakeholders and Roles}

Designers: Collaborate with builders, communities, owners, and government

Builders: Collaborate with owners, utilities, and city/other government agencies Owners: Community association

Utilities/commissions: Respond to designer, building, and community association

City, local, and state government: Provide codes and state regulation to design/build communities

Third-party providers: Function as vendors and technologists

\section{Existing Resources}

Codes

Codes such as those developed by ICC and at the state and local level

U.S. Department of Energy publications

Regulations

Government energy credits and incentives

Guidelines/consumer information on products 


\section{Figure 4-2. Owner Needs and Behavior Priority Guidance Element: Guidelines for Collection and Analysis of Home Energy Data}

\section{Description:}

Designers, builders, and homeowners all need access to energy data to understand and measure the performance of NZE homes. Two sets of guidelines could be drafted to improve access to these data: for design professionals on the development of appropriate and useful technology, and for builders and consumers on the implementation, operation, and maintenance of the technology.

Building Delivery Stage: Construction, commissioning, operation, and maintenance.

Technologies and Home Applications: Sensor, monitoring system, home area networks/information technology, analysis tools (perhaps third-party operation), and home display.

\section{Challenges and Barriers}

- Lack of homeowner access to relevant real-time data on energy use.

- Inadequate or missing data management collection standards.

- Difficulty incorporating other high-performance goals into metrics (e.g., IAQ, water use, health of occupant, security).

\section{Goals and Objectives}

- Occupants have access to real-time information on building performance to better ensure performance at netzero level.
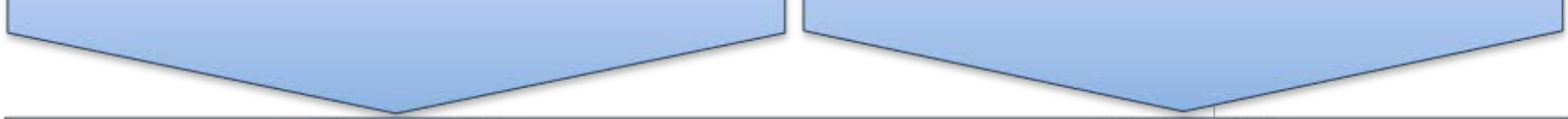

\section{Steps to Develop/Implement Guidance Element}

- Develop technical standards, drawing on any existing resources.

- Tie standards to NZE home performance.

- Work with builders and designers to vet standards.

- Develop commissioning procedures that will support guidelines.

\section{Measures of Success}

- Amount of dollars saved through guidelines.

- Proven seamlessness of use of guidelines.

\section{Stakeholders and Roles}

Technology developers: Develop products according to standards Utilities: Interconnect with energy and communication networks Standards developing organizations: Develop guidelines and standards Builders/architects: Implement guidelines in design process Service providers: Provide business opportunities Building owners/occupants: Share implementation responsibility Realtors, bankers, appraisers, and utilities: Use data to perform roles better

\section{Existing Resources}

Institute of Electrical and Electronics Engineers, Association of Home Appliance Manufacturers

Variety of standards developing organizations 


\section{Figure 4-3. Owner Needs and Behavior Priority Guidance Element: Guide to Building and Marketing High-Efficiency Homes}

\section{Description:}

Builders and developers could benefit from guidelines on how to profitably build and market high-efficiency houses for diverse market segments. The guidelines would drive broader builder participation in the high-efficiency home market as well as demonstrate building techniques and practices that increase energy efficiency without significantly raising construction costs.

Building Delivery Stage: Pre-design, design, and construction.

Technologies and Home Applications: Design and construction practices, appliances, and systems (HVAC, plumbing).

\section{Challenges and Barriers}

- Achieving credibility with builders-the builder community must be involved.

- Overcoming inertia of construction industry practices.

\section{Goals and Objectives}

- Broader builder participation in the high-efficiency home market.

- Builders understand techniques/practices that increase energy efficiency without raising costs.

\section{Steps to Develop/Implement Guidance Element}

- Bring the most appropriate stakeholders to the table to develop guidelines, including builders.

- Write the guideline based on existing models.

- Broadly distribute the guide through credible channels.

- Follow up with builders and developers to increase uptake of guidelines.

- Publicize success stories throughout the builder and user communities.

\section{Measures of Success}

- More energy-efficient houses are on the market and purchased.

\section{Stakeholders and Roles}

Builders: Establish credibility through use

Realtors: Build credibility and market knowledge

Energy efficiency experts: Provide technical input

Product manufacturers: Provide technical and cost information

Social scientists: Provide input on motivation/buy-in

\section{Existing Resources}

U.S. Department of Energy publications

ASHRAE guides

National Institute of Building Sciences 


\section{Figure 4-4. Owner Needs and Behavior Priority Guidance Element: Mass Purchase to Attract Investment in Producing NZE homes}

\section{Description:}

This expedited approach is to establish a competitive, multi-year program for the high-volume purchase of low-cost, customizable, super-high-performance housing. The objective would be to achieve a declining unit cost over time (single-family, clustered, and multi-family—up to three stories) through innovative manufacturing and production techniques.

Building Delivery Stage: Pre-design, design, construction, and commissioning.

Technologies and Home Applications: Industrial design for manufacturing and site assembly.

\section{Challenges and Barriers}

- Building the contingent market commitments to purchase homes once they are built.

- Resistance among builders and trade associations to mass home manufacturing and other innovations.

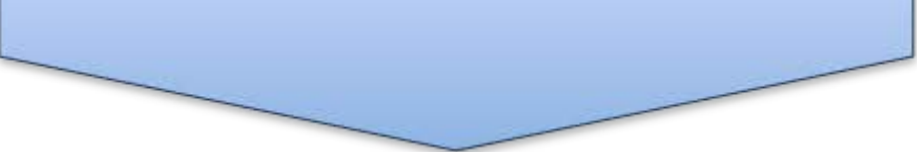

\section{Goals and Objectives}

- Bring NZE homes to the scale needed for cost-effective new construction and retrofits.

- Expand capability while reducing purchase and operating costs.

- Spur innovation in home manufacturing processes and new home technologies.

\section{Steps to Develop/Implement Guidance Element}

- Develop mass purchase approach with methods applicable to the scope of American Society of Heating, Refrigerating and Air-Conditioning Engineers 90.2.

- Define the first market (e.g., U.S. Department of Defense (DOD), U.S. Department of Housing and Urban Development (HUD), other public and government housing authorities).

- Develop provisional home specifications with goals and deliverables (e.g., number of models required).

- Seek reviews by potential buyers to identify issues.

- Publicize to industry to improve specifications and iterate.

- Establish oversight and implementation, and manage the bid process.

- Monitor delivery of homes to specifications and their purchase.

Measures of Success

- Consumers recognize the value of the NZE home package.

- Industrial design reduces costs and dramatically improves energy efficiency above the standard.

\section{Stakeholders and Roles}

Agencies: Become first customers (HUD, DOD)

Manufacturing investors: Capitalize manufacturing

Trades: Install, finish (trim, décor, etc,), and perform retrofits

Realtors and builders: Carry to private market

Utilities: Profit from incentives to capitalize on customer side

State and local government, tribes: Further sustainability goals

\section{Existing Resources}

Lessons learned from similar models:

- Super Efficient Refrigeration Program

- Erie Canal

- Transcontinental railroad

- National Aeronautics and Space Administration

- Super Window Bulk Purchase Program (DOE) 


\section{Figure 4-5. Owner Needs and Behavior Priority Guidance Element: Buyer/Owner Guide for NZE Homes}

\section{Description:}

Providing homeowners with a guide that clearly explains how the home functions as a whole system, and how to operate and maintain individual systems within it, would both increase the knowledge of homebuyers and homeowners so that they can make better purchase and consumption decisions as well as raise their comfort level with the concept of NZE homes.

Building Delivery Stage: Purchase, commissioning, operation, maintenance; purchase stage occurs after construction.

Technologies and Home Applications: Treating home as a whole system, and how to operate and maintain individual systems within it.

\section{Challenges and Barriers}

- Various vested interests may object or oppose the use of a buyer/owner guide.

- Homebuyer/homeowner lack of knowledge about home functions and how to operate and maintain them efficiently.

\section{Goals and Objectives}

- Raise knowledge of homebuyers in making energy efficient purchasing decisions.

- Increase the comfort level of homeowners in managing NZE homes.
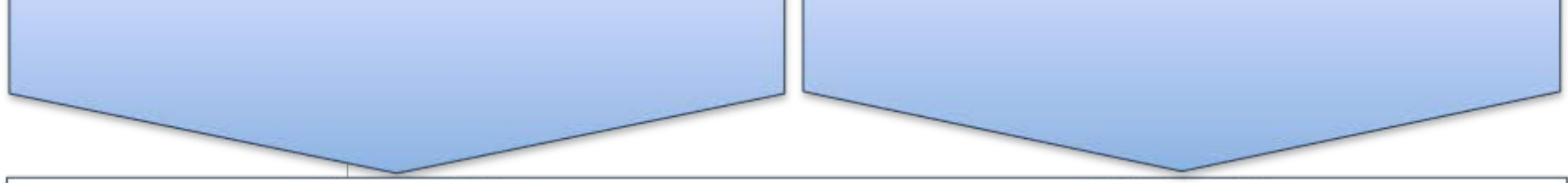

\section{Steps to Develop/Implement Guidance Element}

- Conduct behavioral research on homebuyers, homeowners, and realtors.

- Bring in credible participants, including consumers, realtors, builders, and technology experts.

- Develop a format that is user-friendly and simple.

- Conduct broad outreach and marketing.

\section{Measures of Success}

- Buyers drive market toward more energy-efficient homes and owners operate more energy-efficient homes.

\section{Stakeholders and Roles}

Buyers (homeowner): Provide user perspective

Realtors: Provide seller perspective

Builders: Add credibility to guidelines

Social scientists: Add knowledge to support guideline development

Marketing specialists: Add knowledge to support guideline development

\section{Existing Resources}

Only limited resources exist today. 


\section{Figure 4-6. Owner Needs and Behavior Priority Guidance Element: Education and Credentialing}

\section{Description:}

Education and credentialing of the workforce is needed to support development of NZE homes. Expansion of the technical school and professional school curricula will provide support for more widespread construction and proper installation of NZE home components. Credentialing will help consumers recognize qualified experts and build expertise over time as the base of NZE knowledge grows.

Building Delivery Stage: Construction.

Technologies and Home Applications: All work serviced by quality design and installation procedures.

\section{Challenges and Barriers}

- Lack of a science-based curriculum for training NZE trade professionals as a basis for credentialing the trade professions.

- Increased time requirement for trades to come up to speed on NZE construction and technology.

- Ability to integrate with other labeling and code programs.

\section{Goals and Objectives}

- Establish an expert delivery infrastructure.

- Credential a community of experts qualified in NZE home design and construction.

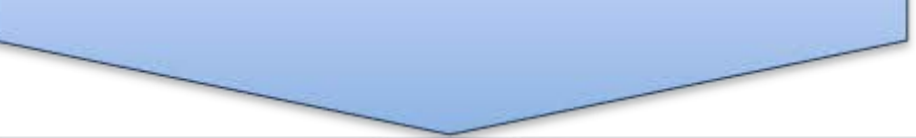

\section{Steps to Develop/Implement Guidance Element}

- Take steps to create enhanced training curricula for the design and building trades, focusing on net-zero home construction.

- Establish incentives for time-constrained trades.

- Require certified design and building trade workforce for any/all NZE home-related work.

\section{Measures of Success}

- Percentage of professionals and trades credentialed.

- Quality product delivered to homeowner.

\section{Stakeholders and Roles}

Architects: Apply education to better design NZE homes

Engineers: Make buildings operational and functional

Home Energy Rating System Raters: Rate the home, deliver the score

Trades: Apply education and credentialing to home building Quality Assurance providers: Evaluate and keep track of energy value inputs

\section{Existing Resources}

Building Science Corporation curriculum

New York State Energy Research and Development Authority

Advanced Buildings Program

Building Performance Institute

Energy Star for New Homes Programs 


\section{CROSS-CUTTING CONSIDERATIONS}

A number of cross-cutting concepts were identified that may not directly support the development of a future guidance document but are important considerations for successful NZE home implementation. These include overall consideration for guidelines; renewable energy options for both individuals and communities; incentives that go beyond the use of guidelines or similar mechanisms; and education and training for designers, builders, and homeowners.

Overall considerations for guidelines should include the following:

- Climate, water, and geographic considerations

- Indoor environmental quality

- Economics: cost and construction options

- Unbiased opinions

- Guidance for new as well as existing homes

- Consistent definitions for NZE

One of the most important considerations is that definitions of what constitutes NZE are currently inadequate or non-uniform. Good definitions are needed to drive equipment solutions. The lack of a consensus-based definition, including purpose and scope (e.g., energy only, or high-performance), creates uncertainties in how to develop and apply technologies, equipment, and designs that are truly "net-zero."

\section{Figure 5-1. NZE Definition}

The building community has embraced the idea of net-zero energy buildings and defined it as: buildings that generate as much energy through renewable means as is consumed by the building. 1,2

1. National Science and Technology Council, "Federal Research and Development Agenda for Net-Zero Energy, High Performance Green Buildings" October 2008.

2. American Society of Heating, Refrigerating, and Air-Conditioning Engineers, "ASHRAE Research Strategic Plan 2010-2015: Navigation for a Sustainable Future"
NZE definitions are still somewhat generic (see Figure 5-1) and do not provide adequate information on the desired "energy threshold” to optimize building energy consumption prior to renewable system integration. Some buildings that are claimed to have achieved NZE status do so by way of surplus renewable energy generation without optimizing basic building energy consumption. NIST intends to provide a framework for the construction of NZE homes that will fulfill the larger objective of energy efficiency. This step is a preliminary one that aims to establish a building design 
strategy and framework that will eventually contribute to the larger goal of global sustainability. Although we recognize that a building relies on inputs and outputs to the geo-biosphere, topics such as site sustainability, water use efficiency and the building's impact on atmosphere, materials and resources will not be addressed in this guidance.

Renewable energy options at the individual and community levels are needed to facilitate understanding and optimize the selection of on-site power and heat generation, a critical component of the NZE strategy. This includes fuel cells, solar, wind, micro-combined heat and power (CHP), and geothermal systems.

Micro-CHP probably has few guidelines available today. A community of NZE homes could desire a shared CHP system, for example, for approximately 100 homes. In general, there are issues with the business plan of community power for utility systems of this smaller size (e.g., how will power costs be shared?). There is substantial reluctance in the business community to invest at this scale. There are a few exceptions where small community CHP systems have been built and successfully operated; these could provide models for future communities. Permitting and siting of these utilities can also create challenges; some jurisdictions, for example, have regulations where the community power line cannot cross a public road.

Incentives beyond guidelines, codes, or standards are needed to encourage designers and builders, as well as homeowners, to select NZE technologies and to operate and maintain them properly. Some potential approaches include the following:

- Zero Energy Home Mortgage at a 1\%-2\% lower rate than the market to provide financial incentives and could be coupled with appraisals that more accurately assign value to NZE home components.

- Guaranteed energy savings evaluation program to ensure that consumers get what they paid for in terms of energy performance over some period of time.

Education and training for consumers, builders, government, insurers, and realtors is needed to raise awareness of the value and benefit of NZE homes, and to facilitate proper design and construction. Although we have focused on many types of stakeholders and a variety of design professionals, it is important that NZE home guidance include consumers as well Building science suffers and basic NZE concepts will not be successfully transferred when consumers lack the knowledge to understand their energy use patterns and how to choose NZE home components. Convincing consumers to purchase NZE home options will require education. Offering a homeowner manual for selection and purchase of NZE homes was identified as a priority in this regard. Curricula designed for grades $\mathrm{K}-12$ would be another approach for embedding positive perspectives of NZE within the family. Training is also needed for owners and operators of NZE homes to ensure efficient 
operation and maintenance after purchase - and to validate actual energy performance.

Designers, builders, and the real estate community are also generally poorly informed about how to design, construct, and market NZE homes. Education and training on NZE is needed throughout the building industry. Targeted marketing campaigns, advertising, sponsorships, or other means that elevate the image of NZE homes and make consumers aware of potential benefits could accelerate market acceptance. Engaging behavioral scientists in the design and construction of NZE homes is another way to understand consumer preferences and devise effective marketing strategies. Ultimately, the effectiveness of NZE home guidance rests on identifying the crosscutting technical gaps, accepting the research challenges and working with all of the stakeholders to get to the goal. A number of cross-cutting concepts were identified that may not directly support the development of a future guidance document but are important considerations for successful NZE home implementation. These include overall consideration for guidelines; renewable energy options for both individuals and communities; incentives that go beyond the use of guidelines or similar mechanisms; and education and training for designers, builders, and homeowners. 


\section{Appendix A. Acronyms}

ACCA Air Conditioning Contractors of America

AHRI Air Conditioning, Heating and Refrigeration Institute

ASHRAE American Society of Heating, Refrigerating and Air-Conditioning Engineers

BTU British thermal unit

CHP Combined heat and power

DOD U.S. Department of Defense

DOE U.S. Department of Energy

EPA U.S. Environmental Protection Agency

HUD U.S. Department of Housing and Urban Development

HVAC Heating, ventilation and air conditioning

IAQ Indoor Air Quality

ICC International Code Council

IECC International Energy Conservation Code

LCA Life cycle analysis

MOTS Methods of test

NAFA National Air Filtration Association

NIST National Institute of Standards and Technology

NZE Net-zero energy

OEM Original equipment manufacturer

PITI Valuation of Principal, Interest, Taxes, Insurance

PITIE Valuation of Principal, Interest, Taxes, Insurance, and energy cost consideration

PHIUS Passive House Institute, U.S.

SEER Seasonal Energy Efficiency Rating 